\title{
AVALIAÇÃO DO MÉTODO DE BALANÇO DE CALOR NA ESTIMATIVA DA TRANSPIRAÇÃO EM TOMATEIROS, PLANTAS DE MILHO E MUDAS DE LIMOEIRO
}

\section{JOSÉ EFRAIN TREJO-CHANDIA}

Engenheiro Agrônomo

Orientador: Prof. Dr. LUIZ ROBERTO ANGELOCCI

Tese apresentada à Escola Superior de Agricultura "Luiz de Queiroz", Universidade de São Paulo, para obtenção do título de Doutor em Agronomia, Area de Concentração: Solos e Nutrição de Plantas.

PIRACICABA

Estado de São Paulo - Brasil

Setembro - 1997 
Dados Internacionais de Catalogação na Publicação (CIP) DIVISÃO DE BIBLIOTECA E DOCUMENTAÇÃO - Campus "Luiz de Queiroz"/USP

\section{Trejo-Chandia, José Efraim} Avaliaçăo do método de balanço de calor na estimativa da transpiraçăo em tomateiro, plantas de milho e mudas de limoeiro. - - Piracicaba, 1997.

$$
75 \text { p. : il. }
$$

Tese (doutorado) - Escola Superior de Agricultura Luiz de Queiroz, 1997. Bibliografia.

1. Balanço hídrico 2. Calor 3. Limāo 4. Milho 5. Relaçāo solo-planta-atmosfera 6. Tomate 7. Transpiraçāo I. Título 


\title{
AVALIAÇÃO DO MÉTODO DE BALANÇO DE CALOR NA ESTIMATIVA DA TRANSPIRAÇÃO EM TOMATEIROS, PLANTAS DE MILHO E MUDAS DE LIMOEIRO
}

\author{
JOSÉ EFRAIN TREJO-CHANDIA
}

Aprovada em: 31.10 .97

Comissão Julgadora:

Prof. Dr. Luiz Roberto Angelocci

ESALQ/USP

Prof. Dr. Marcos Vinicius Folegatti

ESALQ/USP

Prof. Dr. Antonio Roberto Pereira

ESALQ/USP

Prof. Dr. Carlos Manoel Pedro Vaz

CNPDIA/EMBRAPA

Prof. Dra. Teresinha de Jesus Deleo Rodrigues

FCAVJ/UNESP

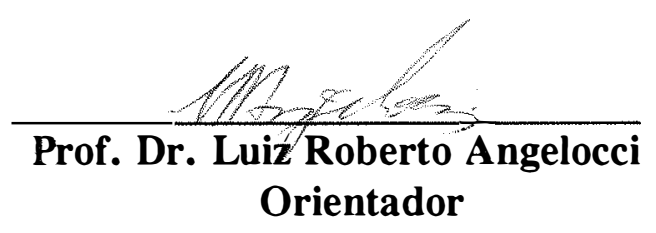


Aos meus pais BALDRAMINA CHANDIAS e EUFEMIO TREJO,

pelo exemplo de honestidade e luta e os esforços na formação dos filhos

MINHA GRATIDÃO.

A minha esposa LOURDES CLEA MOREIRA pelo amor, apoio e incentivo e aos meus filhos, que justificam qualquer sacríficio.

DEDICO.

A Escola Superior de Agricultura "Luiz de Queiroz" ESALQ; por me conceder o privilégio de ser um dos seus filhos.

OFEREÇO. 


\section{AGRADECIMENTOS}

Ao Centro Universitário Regional do Litoral Atlântico (CURLA), Escola Superior de Agricultura "Luiz de Queiroz" (ESALQ), Organização dos Estados Americanos (OEA) e ao Conselho Nacional de Desenvolvimento Científico e Tecnologico (CNPq) pela oportunidade de realização deste curso.

Aos professores Luiz Roberto Angelocci e Ricardo Ferraz de Oliveira, pela orientação, esforço dispensado no decorrer deste trabalho, amizade, confiança e disponibilidade demonstradas.

A Lourdes Clea Moreira, esposa e companheira, Vinicius Eufemio e Luis Enrique filhos e companheiros por todo o amor, gestos de compreensão e partilha neste valioso tempo de construção em Piracicaba - S.P.

Aos amigos estrangeiros pela alegre convivência no tempo de estudo especialmente a Axel Gárcia Gárcia e Selma Regina Maggiotto pelo solidário apoio brindado durante a realização do trabalho. 
SUMÁRIO

Página

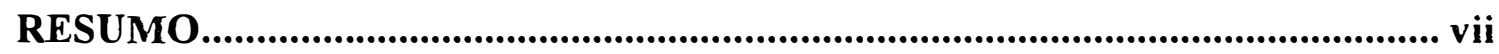

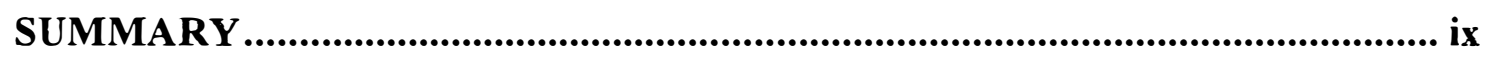

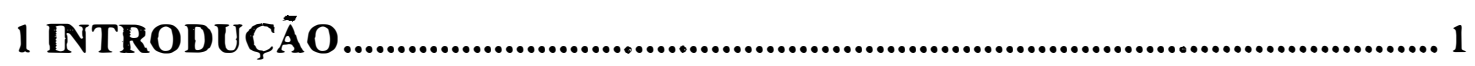

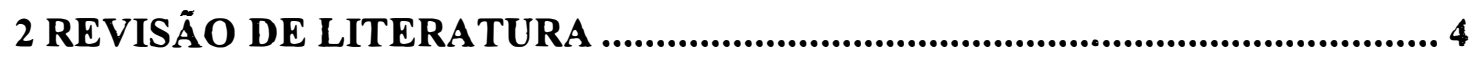

2.1 Medidas de fluxo de seiva e seu uso na estimativa da transpiração ................. 4

2.1.1 Métodos de traçados quimicos, traçadores radioativos e método magnético hidrodinamico........................................................................................ 5

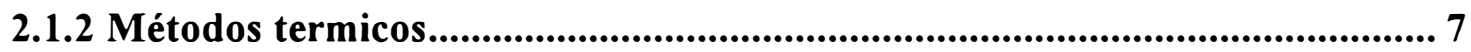

2.1.2.1 Método de pulso de calor................................................................................. 8

2.1.2.2 Método de sonda de dissipação calórica ......................................................... 9

2.1.2.3 Método de balanço de calor........................................................................ 10

2.2 Aplicações e problemas do método de balanço de calor....................................... 12

3 MATERIAL E MÉTODOS ......................................................................... 20

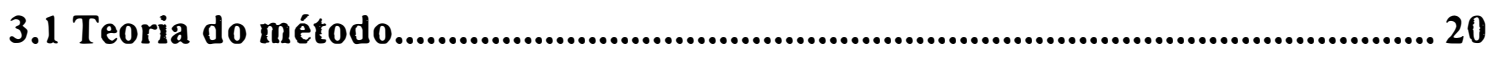

3.2 Montagem dos sensores...................................................................................... 25

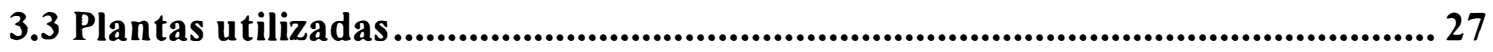

3.3.1 Herbaceas.............................................................................................................. 27

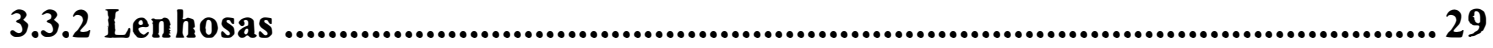

3.4 Procedimentos dos testes .................................................................................. 29

3.5 Testes de resposta dinâmica ..................................................................................... 31 


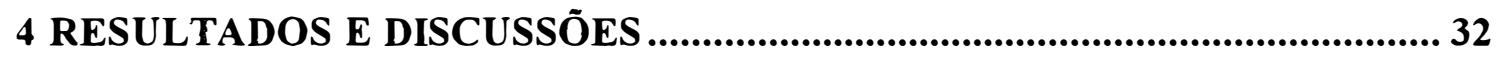

4.1 Comparação das estimativas de fluxo de seiva pelo método de balanço de calor com as medidas de transpiração por pesagem.......................................... 32

4.1.1 Herbáceas............................................................................................................... 32

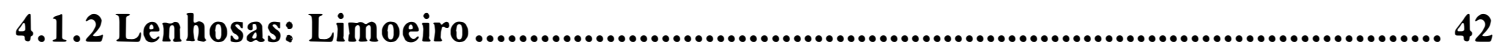

4.2 Avaliação do desempenho do método e dos sensores de balanço de calor........ 46

4.2.1 Dinâmica dos fluxos dissipativos do calor fornecido ........................................... 46

4.2.2 Fontes potenciais de erro na estimativa dos fluxos de seiva.............................. 48

4.2.2.1 Uso dos coeficientes Kc e Ksh ............................................................................ 48

4.2.2.2 Medidas de temperatura para estimativa dos fluxos condutivos e

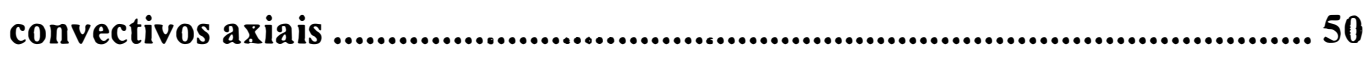

4.2.2.3 Estimativa da variação de armazenamento de calor no caule ..................... 52

4.2.3 Resposta dinâmica do sistema............................................................................... 59

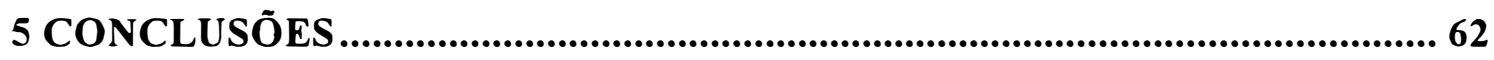

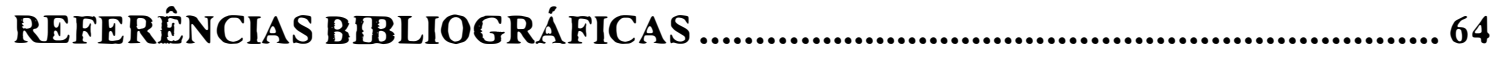




\title{
AVALIAÇĀO DO MÉTODO DE BALANÇO DE CALOR NA ESTIMATIVA DA TRANSPIRAÇĀO EM TOMATEIROS, PLANTAS DE MILHO E MUDAS DE LIMOEIRO
}

\author{
AUTOR: JOSÉ EFRAIN TREJO-CHANDIA \\ ORIENTADOR: PROF. DR. LUIZ ROBERTO ANGELOCCI
}

\section{RESUMO}

A quantificação da água transpirada pelas plantas é de importância fundamental em estudos das relações hídricas no sistema solo-planta-atmosfera, como no manejo da água para fins agricolas; contar com métodos precisos, confiáveis e baratos para a determinação da transpiração tem sido durante muito tempo o objetivo dos pesquisadores nas areas pertinentes.

O método de balanço de calor é atualmente muito usado para monitorar o fluxo de água em plantas de diversas espécies. Neste trabalho avaliou-se a aplicabilidade do método, assim como a resposta dinâmica do sistema e erros introduzidos na estimação dos fluxos de seiva em duas espécies herbáceas (tomate e milho) e uma lenhosa (mudas de limoeiro). Os sensores foram avaliados em plantas crescendo em vasos em casa de vegetação sob condições naturais de temperatura e radiação solar, os sinais emitidos foram registrados cada segundo e armazenados em sistema de aquisição de dados a cada 30 minutos. As medidas dos flunos de seiva estimados foram comparadas com 
medidas gravimétricas e submetidas a análise de regressão linear para verificar a precisão dos sensores. O método permitiu medidas de fluxo transpiratório com diferença média de $8,5 \%$ para tomate, $15 \%$ em milho e $11,5 \%$ em limoeiro, na escala horária, e de $8,1 \%$ em tomate, $13,6 \%$ para milho e $13,3 \%$ para limoeiro, em uma escala de 10 horas, sempre com tendência de superestimativa do fluxo de seiva em relação à transpiração.

Os valores superiores fornecidos pelo método de balanço de calor ocorreram sempre no período da manhã e nas horas de maior demanda hídrica da atmosfera, e podem ser uma indicação da existência de erros no método. Uma fonte de erro pode ter sido a adoção de um só valor para o coeficiente de transferência calorífica (Ksh) do fluximetro que mede a transferência radial de calor; e há indicações também, de que isolamento térmico dos sensores deveria ter maior espessura para maior eficiência nos momentos de altas flutuações térmicas. Os valores da constante de tempo de 4 a 20 minutos indicam que os sensores apresentaram boa resposta dinâmica podendo detectar variações nos fluxos de água dentro dessa faixa de tempo, o que é um indicativo do potencial de aplicação do método em estudos da dinâmica do transporte hídrico em intervalos de essa ordem de grandeza em tomateiro, milho e limoeiro para fins fisiológicos e agronômicos. 


\title{
EVALUATION OF THE HEAT BALANCE METHOD TO ESTIMATE THE TRANSPIRATION RATES OF TOMATOES, CORN AND LEMON PLANTS
}

\author{
AUTHOR: JOSÉ EFRAIN TREJO-CHANDIA \\ ADVISER: PROF. DR. LUIZ ROBERTO ANGELOCCI
}

\section{SUMMARY}

Quantification of water transpired by plants is of fundamental importance in studies of water relations for the soil-plant-atmosphere system as well as for the agricultural water management. The development of a cheap, precise and confiable method to determine plant transpiration has been, for a long time, the main objective of plant physiologists.

Heat balance method is currently used to track water flow in different plant species. In this study aplicability of the method and the dynamic response of the stem gauges and the sap flow estimation errors for two herbaceous (tomatoes and maize) and one woody (lemon) plants were evaluated. Gauges were evaluated on potted plants grown in a greenhouse under natural temperature and solar radiation conditions. Signals were registered every second and were stored in a datalogger every 30 
minutes. Estimated sap flows were compared to gravimetric weight losses. It was also performed a regression analysis to verify gauge precision.

Differences between sap flow estimated by the heat balance method and transpiration measured by gravimetric weight losses average $8,5 \%$ for tomatoes, $15,2 \%$ for corn and $11,5 \%$ for lemon plants in the hourly scale; and $8,1 \%$ for tomatoes; $13,6 \%$ for maize and $13,3 \%$ for lemon plants in the 10 hour scale when compared to gravimetric water losses. Results showed a super estimation for the sap flow compared to gravimetric measurements.

Higher values generated by the heat balance method ocurred always during the morning and in the hours of highest evaporative demand. That fact might be an indication of method error. Another error source may be the adoption of a single value for the heat transference coefficient (Ksh) of the fluximeter that measures radial heat flux. The results suggest that gauges thermal isolation should be thicker in order to improve its efficiency in the moments of high environmental temperature fluctuations. Values of time constant ranging from 4 to 20 minutes indicated that gauges had a good dynamic response and were able to detect sap flow variations in that time period. It can be concluded that the Heat Balance Method was proved to be accurate in determining water losses for tomatoes, maize and lemon plants. 


\section{INTRODUÇÃO}

A quantificação da água ranspirada pelas plantas, num determinado período, é de importância fundamental em estudos das relações hídricas no sistema soloplanta-atmosfera, sendo de interesse para diversos ramos da atividade humana, pela importância quantitativa que esse processo representa em relação à perda de água das superfícies vegetais naturais ou cultivadas.

No manejo da água para fins agrícolas, o conhecimento das taxas de transpiração auxilia na elaboração de balanços hídricos e na determinação da frequência de irrigação. Quando se trabalha com culturas que cobrem de forma descontínua o solo, em sistemas de cultivo, como pomares, as plantas podem ser tratadas de forma praticamente individualizadas no que se refere ao consumo de água. Um exemplo é a irrigação com fornecimento localizado de água, na qual o conhecimento da transpiração individualizada das plantas é muito importante, justamente porque ela apresenta o consumo mínimo necessário para mantê-las em bom estado hídrico. Nesse caso, a determinação da transpiração é um dos meios de melhorar o manejo da água e, consequentemente, aumentar a produção, melhorar a qualidade dos frutos, utilizar de forma mais eficiente os recursos hídricos em regiões onde eles são escassos, reduzir o fornecimento excessivo de 
água e a consequente poluição dos lençóis freáticos. O objetivo dos pesquisadores que trabalham nas áreas pertinentes é ter métodos precisos, baratos e confiáveis para a determinação da transpiração. Métodos de determinação direta como as câmaras gasosas, interferem com o microclima da planta. Métodos de traçadores radioativos também podem ser usados, mas há restrições teóricas e práticas ao seu emprego.

Os métodos baseados no fornecimento de calor ao tronco, caule ou ramos têm recebido grande atenção nos últimos tempos porque utilizam princípios relativamente simples e são de boa aplicabilidade no campo. Na verdade, destinam-se às medidas volumétricas do fluxo de seiva em plantas intactas que, sob determinadas condições pode ser admitido como equivalente à transpiração. O método de balanço de calor tem sido bastante estudado e sua potencialidade na medição de fluxo de seiva foi avaliada em numerosas espécies de plantas herbáceas como lenhosas. Em condições de campo, sua aplicabilidade tem sido estudada na partição da evapotranspiração para avaliar o fenômeno de transporte de energia em ambientes agrícolas, para estudar o efeito de retardadores de crescimento sobre plantas hortícolas em ambientes urbanos, para avaliar o uso da água e na medição de perdas de água em ecossistemas naturais. A expectativa sobre sua potencialidade pode ser avaliada pelo fato de que atualmente ele é comercializado como uma solução para a determinação do consumo de água de pequenas árvores, como base para o manejo da irrigação. Mas, apesar dessa expectativa e de seus aspectos favoráveis, o método apresenta limitações que poderão ser diminuídas com a evolução do conhecimento de seus aspectos teóricos e das técnicas empregadas. 
No momento, o método é considerado uma ferramenta nas pesquisas e sua aplicabilidade está sendo bastante testada em um número muito grande de espécies, bem como sendo desenvolvidos estudos para o seu aperfeiçoamento, para melhorar a precisão das medidas.

Os objetivos do presente trabalho foram avaliar a aplicabilidade do método de balanço de calor para estimar fluxos de seiva em duas espécies herbáceas (milho e tomate) e uma espécie lenhosa (limoeiro), verificar a representatividade da estimativa em relação aos fluxos de transpiração, testar a resposta dinâmica do sistema e estudar erros introduzidos na estimativa dos fluxos de seiva. 


\section{REVISÃO DE LITERATURA}

\subsection{Medidas do fluxo de seiva e seu uso na estimativa da transpiração}

Os métodos usados para medir fluxo de seiva em caules de plantas são similares aos métodos usados na indústria para a medição de fluídos em tubulações devido à similitude dos fluxos; entretanto, o progresso na quantificação das medidas de fluxo de seiva vem sendo estimulado pelo reconhecimento das diferenças desses fluxos nos diferentes sistemas, levando à derivação de teorias e métodos próprios para seu uso em plantas.

Os métodos disponíveis atualmente para medir fluxo de seiva (a “corrente transpiratória”) baseiam-se na sua marcação por corantes ou isótopos radioativos (métodos químicos), na submissão do fluxo de seiva a um campo magnético (método magnético hidrodinâmico) e no aquecimento da seiva (métodos térmicos). 


\subsubsection{Métodos de traçadores químicos, traçadores radioativos e método magnético}

\section{hidrodinâmico}

Os traçadores químicos podem ser corantes (fluorcromos, fucsina básica, toluidina) e são usados em espécies com caules e ramos transparentes. O corante é adicionado no meio radicular ou injetado no caule num tempo zero e sua primeira ocorrência numa distância selecionada do ponto de injeção é detectada (caso não seja possível visualizar essa ocorrência, pode-se detectá-lo por fluorescência de ultravioleta no caso de uso de fluorcromos), determinando-se então a velocidade da seiva (Slavik, 1974). Uma alternativa é "marcar" a seiva com solução de $\mathrm{NaCl}$ e medir o tempo desde o fomecimento da solução e o acréscimo repentino da condutividade elétrica entre eletrodos introduzidos no caule a certa distância do ponto de fornecimento da solução (Lundegärdh, 1954).

Podem ser utilizados radioisótopos como traçadores, acompanhando-se o movimento da radioatividade com um tubo Geiger-Muller colocado a certa distância do ponto de injeção do composto marcado. O Trítio $\left({ }^{3} \mathrm{H}\right)$ é o isótopo que tem sido mais utilizado, mas devido a sua fraca emissão beta, amostras têm que ser coletadas periodicamente para sua análise em laboratório; ${ }^{32} \mathrm{P}$ passou a ser uma boa alternativa, já 
que permite o monitoramento da radioatividade diretamente no campo, por sua forte emissão beta.

Waring \& Roberts (1979) usaram água tritiada $\left({ }^{3} \mathrm{H}\right)$ e $\left({ }^{32} \mathrm{P}\right)$ para medir transpiração em árvores (Pinus sylvestris L.) injetando os traçadores em vários furos na base do tronco e detectando a atividade específica na superfície, selecionando e marcando os pontos onde a radioatividade atingia $5 \mathrm{cps}$ e retirando amostras nesses pontos para o monitoramento do trítio $\left({ }^{3} \mathrm{H}\right)$, até uma distância de $6 \mathrm{~m}$ acima do ponto de aplicação, reportando que ambos os traçadores são transportados por fluxo de massa em taxas similares e podem definir adequadamente a rota de transporte de água no caule, embora o tritio exibia propriedades de difusão. Os autores encontraram variações na densidade e no conteúdo relativo de água da madeira a diferentes alturas (decréscimo vertical), sugerindo que essas variações podem ser fontes de grandes erros quando um só valor de densidade é assumido. Doley \& Grive (1966) e Swanson (1972) sugeriram que variações no conteúdo relativo de água causam variações na rota de transporte e absorção, conduzindo a erros na interpretação da radiação o que foi posteriormente confirmado por Puritch (1971) e Puritch \& Petty (1971), que demonstraram de maneira convincente que pequenas variações no conteúdo relativo de água, causam grandes variações no transporte e, consequentemente, inconsistências na radiação; além disso não é facil determinar com precisão o tempo do primeiro aparecimento da radioatividade no ponto selecionado, devido efeito de "radiação de fundo", também reportado por Heine \& Denis (1973). 
O método magnético hidrodinâmico foi descrito em detalhe por Sheriff (1972). Basicamente a técnica envolve a aplicação de um campo magnético uniforme em ângulo reto à direşão do fluxo; assim, uma tensão é induzida no fluído, perpendicularmente à direção do fluxo e à direção do campo magnético; essa voltagem é diretamente proprocional à densidade do fluxo fluído e pode ser medida mediante eletrodos e usada para determinar o fluxo. A tensão pode ser calculada pela equação:

$$
\mathrm{V}=10^{-8} 2 \mathrm{R} \cdot \mathrm{B} \cdot \overline{\mathrm{V}}
$$

em que $\mathrm{R}$ é o raio interno do tubo $(\mathrm{cm})$, B é a densidade do fluxo magnético (gauss) e $\mathrm{V}$ é a media da velocidade instantânea do fluído $\left(\mathrm{cm} \mathrm{seg}^{-1}\right)$. Uma grande desvantagem da técnica, além da dificuldade da construção dos aparelhos e a calibração dos mesmos, é a sua sensibilidade que, embora seja independente de fatores físicos (temperatura, velocidade, viscosidade) é inversamente proporcional ao raio do caule, uma vez que $\mathrm{S}=$ $10^{-8} 2 \mathrm{~B} / \pi \mathrm{R}$, sendo $\mathrm{S}$ é a sensibilidade (volts $\mathrm{cm}^{-3} \mathrm{seg}^{-1}$ ), o que restringe sua aplicação a espécies de diâmetros pequenos (de 1 a 4 mm).

\subsubsection{Métodos térmicos}

Baseiam-se no aquecimento da corrente ranspiratória e no acompanhamento da transferência de calor pela corrente. Pelo fato de perturbarem pouco o sistema estudado, são utilizados com mais frequência que os métodos anteriores. De acordo com a 
técnica e os princípios utilizados de fornecimento de calor podem ser classificados em 3 grupos (Valancogne, 1988): a) Método de pulso de calor; b) Método de sonda calórica ou do fluximetro lateral; e c) Método de balanço de calor.

\subsubsection{Método de pulso de calor}

Proposto empiricamente na década de 30 (Huber, 1932; Huber \& Schmidt, 1937), foi desenvolvido teoricamente por Marshall (1958) e Closs (1958). Uma boa descrição do método, incluindo a derivação da teoria, é dada por Cohen et al. (1981, 1988). Um pulso de calor é usado como traçador para determinar a velocidade da seiva. Para isso, duas pequenas sondas são inseridas radialmente dentro do caule; a sonda inferior contem um dissipador de calor e a sonda superior um ou mais sensores de temperatura; um pulso de calor é aplicado através do dissipador e monitorado pelos sensores. Assim, o tempo para atingir a temperatura máxima é tm, e o tempo para atingir a temperatura máxima em condições de fluxo zero é $\mathrm{t}^{\circ} \mathrm{m}$; sendo $\mathrm{r}$ a distância entre o ponto de aplicação do pulso e os sensores de temperatura, $\rho c$ a calor específico volumétrico da madeira e $C_{w} o$ calor específico da água, a velocidade do fluxo de massa através do caule (Jw é dada pela equação 2).

$$
J w=\frac{\rho_{c} \cdot r\left(1-t m / t^{0} m\right)^{1 / 2}}{C w \cdot t m}
$$


A limitação desta teoria é que somente a velocidade da seiva é medida; o cálculo do fluxo (massa/unidade tempo) da seiva requer o conhecimento da área condutora do xilema, o que representa uma dificuldade adicional. É difícil também obter a constante de tempo; consequentemente, o método requer um fator de conversão empírico e variável, obtido pelo monitoramento da perda de água por perda de peso. Apesar disso, o método continua sendo bastante utilizado.

\subsubsection{Método de sonda de dissipação calórica}

Este método foi proposto por Granier (1985), e utiliza duas sondas de diâmetros pequenos inseridas radialmente no caule, principalmente em lenhosas. Uma sonda contém um fio que dissipa calor e um termopar para a medida da temperatura. A segunda junção contém somente o termopar, para medir a temperatura de referência (sonda de referência). A estimativa de fluído de seiva é determinada empiricamente pelo monitoramento do aumento da temperatura quando o fio dissipador é alimentado com corrente elétrica constante ou, de modo alternativo, variando-se a corrente elétrica aplicada, de maneira a manter uma diferença de temperatura constante.

As equações empíricas para a obtenção do fluxo são obtidas a partir de calibração e são do tipo: 
Calor constante $\quad \mathrm{F}=\mathrm{K} \cdot \mathrm{A}\left(\Delta \mathrm{T}^{\mathrm{O}} / \Delta \mathrm{T}-1\right)^{1,23}$

Temperatura constante $\mathrm{F}=\mathrm{K} . \mathrm{A}\left(\mathrm{Q} / \mathrm{Q}_{0}-1\right)^{1,23}$

sendo que $\mathrm{K}$ é um índice adimensional de fluxo, e Q é a potencia aplicada, o subscrito o é o valor quando o fluxo de seiva é zero.

O método apresenta excelente resposta dinâmica e tem sido usado em lenhosas de grande porte, embora apresente a desvantagem de necessitar calibração e para isso, de se fazer amostragem invasiva do caule para determinação da área efetiva de transporte da seiva.

\subsubsection{Método de balanço de calor}

Medidas diretas de fluxo de massa da seiva usando uma aplicação contínua de calor ao caule foram primeiramente propostas por Vieweg \& Ziegler (1960), e posteriomente por Daum (1967). Pickard \& Puccia (1972), mediante análise matemática de condução e convecção bidimensional de calor em caule, mostraram como o fluxo de massa pode ser obtido pelo acompanhamento das entradas e saídas de calor. 
Duas formas de medidas diretas do fluxo de seiva pelo método de balanço de calor tem sido utilizadas. Cermack et al. (1973) e Kucera et al. (1977) foram os primeiros a utilizar fluxo de seiva como indicador dos processos transpiracionais na antiga Tchecoslovaquia, e desenvolveram um método para realizar medidas diretas de fluxo de massa em árvores mediante o balanço de calor. Nesse método, uma diferença de temperatura é mantida constante entre os sensores localizados acima e abaixo do segmento de caule aquecido mediante a variação da potência aplicada ao conjunto dissipador de calor. A precisão do método em condições de campo foi demonstrada por Shulze et al. (1985); Stockle et al. (1991); Grime et al. (1995). O sensor não requer calibração e a resposta à variação de fluxo de seiva é quase instantânea; entretanto, os eletrodos ou sensores de temperatura devem ser inseridos no tronco, o que limita sua aplicação em caules de diâmetros consideráveis. Além disso, Kucera et al. (1977) sugeriram que a manutenção de gradientes estáveis de temperatura mediante a variação da potência aplicada requer aparelhos eletrônicos sofisticados e o controle individual para cada sensor.

Uma outra modalidade do método de balanço de calor simples, barata e mais estudada atualmente, foi proposta no Japão por Sakuratani $(1981,1984)$, que o empregou em plantas herbáceas. Sua aplicação em lenhosas começou nos Estados Unidos (Baker \& van Bavel, 1987; Steinberg et al., 1989) e na França (Valancogne \& Nasr, 1989). A partir de então, tem sido usado em inúmeros trabalhos em herbáceas e lenhosas, parte deles com objetivo de análise e aperfeiçoamento do próprio método (Kitano \& Eguchi, 1989; Valancogne Nasr, 1989; Heilman \& Ham, 1990; Ishida et al., 1991; 
Weibel \& de Vos, 1994; Chandra et al., 1994; Weibel \& Boersma, 1995; Peressotti \& Ham, 1996) e parte com 'objetivos aplicados, como por exemplo, avaliar o fenômeno de transporte de energia em ambientes agrícolas (Sakuratani, 1987; Ham et al., 1990; Steimberg et al., 1991) e do uso da água (Heilman et al., 1989), para estudar o efeito de retardadores de crescimento sobre plantas hortícolas em ambientes urbanos (Steinberg, van Bavel \& Mc Farland, 1991; Steinberg, Zajicek \& Mc Farland, 1991), para medir perda de água em ecossistemas naturais (Fichtner \& Schulze, 1990), e no monitoramento de danos causados por doenças (Gavloski et al., 1992).

Os seus princípios são tratados em Material e Métodos, mas de maneira simplista, envolve a aplicação de um pequeno fluxo constante de calor a um segmento de tronco, caule ou ramo, medindo-se a partição desse calor nos fluxos condutivos axiais e radiais nos tecidos, na variação de armazenamento de calor no volume correspondente ao segmento, e no calor dissipado convectivamente pela seiva. Este último é calculado como termo residual na equação do balanço, e então transformado em fluxo de seiva através do grau de aquecimento que esta sofre durante sua passagem pelo segmento e da capacidade calorífica da água, assumindo-se ser a água a componente predominante na seiva.

\subsection{Aplicações e problemas do método de balanço de calor}

$\mathrm{Na}$ maioria dos trabalhos nos quais foram feitas comparações entre o vaior estimado do fluxo de seiva e da transpiração das plantas medidas por balanças, têm 
sido encontradas diferenças inferiores a $10 \%$ quando os valores são computados entre 15 minutos e 24 horas, conforme extensa lista de trabalhos citados por Weibel \& de Vos (1994). Para árvores ornamentais, Devitt et al. (1993) reportam diferenças de $18 \%$ em períodos acumulados de 14 a 72 horas e verificaram experimentalmente que era necessário um tempo mínimo de 68 horas de valores acumulados de fluxo de seiva para que se mantivesse um erro abaixo de $10 \%$. Em lenhosas de certo porte a boa concordância somente ocorre em escala diária, porque em intervalo menores ou iguais 4 horas, o fluxo medido próximo à base do tronco representa bem a absorção de água pelas raízes, mas não corresponde necessariamente à transpiração nas folhas (Steinberg et al., 1989; Valancogne \& Nasr, 1993; Schackel et al., 1992).

Em geral, durante o período diumo, há uma defasagem entre absorção hídrica e transpiração, sendo que nos momentos de maior demanda evaporativa a planta usa água armazenada nos tecidos para atender a transpiração em suplemento à água absorvida; se não há deficiência hídrica no solo, a absorção continua a noite, quando a transpiração é bastante restringida ou até anulada, ocorrendo assim a reposição da água retirada dos tecidos (Kramer, 1983).

Simulações numéricas de Baker \& Nieber (1989) mostraram que a exatidão do método é afetada pela anatomia do sistema vascular, sendo possivelmente maior em dicotiledôneas, nas quais o sistema vascular consta de um cilindro contínuo envolvendo a medula ou porção central do caule, do que em monocotiledôneas, que têm um sistema vascular disperso por todo o tecido fundamental. A simulação físico- 
matemática por eles realizada mostrou que a distribuição de temperatura no caule de herbáceas e no próprio sensor é alterada quando o fluxo de seiva aumenta. Como essa temperatura é usada na estimativa de fluxos de calor através de equações unidimensionais de Fourier, segundo Baker \& Nieber (1989), essa alteração faz com que tais equações não sejam exatamente aplicáveis, conduzindo à estimativas pobres nos fluxos, embora os erros sejam auto-compensados e a estimativa final do fluxo de seiva seja razoavelmente exata.

Usando um modelo similar ao de Baker \& Nieber (1989), Ishida et al. (1991) estimaram fluxos de calor em espécies monocotiledôneas e dicotiledôneas, observando nas espécies dicotiledôneas uma pequena variação da temperatura na direção radial, exceto muito perto da porção aquecida. Nos caules das monocotiledôneas, o perfil de temperatura na direção radial mostra variação, vários centímetros acima do elemento aquecedor; consequentemente, a temperatura medida na superfície próxima desse elemento foi maior que a temperatura média da secção transversal do caule, sugerindo que cálculos de fluxo, baseados nestas temperaturas, podem conter erros significativos. Cohen et al. (1993) também sugerem que medidas com o método de balanço de calor podem ser incorretas quando o sistema condutivo é distribuído desigualmente ou irregularmente na secção transversal do caule, devido à falta de equilíbrio térmico entre a superfície externa do caule e a seiva em movimento, principalmente nos momentos de altos fluxos, como sugerido por Baker \& Nieber (1989).

Zhang \& Kirkham (1995), trabalhando com uma espécie monocotiledônea (sorgo) e uma espócie dicotiledônea (girassol), concluiram que a magnitude da taxa do 
fluxo é mais importante que a anatomia do sistema vascular na determinação da precisão do método de balanço de calor.

Em plantas lenhosas, características específicas do caule, como o número de anéis de crescimento condutores de seiva, a dimensão e densidade dos vasos condutivos, o conteúdo hídrico absoluto do ceme e sua variação no tempo (que afeta a sua capacidade calorífica) e a quantidade do fluxo de massa na direção radial de um anel de crescimento à outro, são importantes no balanço de calor. Espécies de madeira dura, denominadas de porosidade difusa, tem vasos relativamente uniformes em tamanho e distribuição, ocupando 20 a $60 \%$ do volume do albumo; estas espécies apresentam condições relativamente mais favoráveis à medição dos fluxos pelo método de balanço de calor. Mas, medições efetivas da temperatura da seiva são bem mais difíceis em espécies que têm porosidade em anel (ex: Quercus sp.), onde os vasos ocupam uma baixa porcentagem volumétrica (5-20\%) do albumo, sendo em sua maioria muito longos, bem como em espécies de madeira mole (ex: Pinus sp.), onde facilmente 5 a 7 anéis de crescimento podem contribuir substancialmente na condução da seiva (Weibel \& de Vos, 1994).

Shackel et al. (1992), ao estudarem possíveis fontes de erro na estimativa dos fluxos de seiva pelo método de balanço de calor em plantas lenhosas, em condições de campo e usando sensores comerciais, reportam a ocorrência de valores muito pequenos e até negativos entre a temperatura da superfície do caule acima e abaixo da fonte aquecedora, o que conduz à superestimativa dos fluxos e a obtenção de fluxos negativos em condiçōes de corrente transpiratória altâ, crros esses atribuídos à influência direta das 
condições ambientais nos sinais do sensor, o que foi verificado por Gutierrez et al. (1994) e Gerdes et al. (1994) em condições de campo, sugerindo que os gradientes de temperatura medidos na superfície do caule não são só consequência da dissipação da potência aplicada ao sensor. Levitt et al. (1991) e Grime et al. (1995), verificaram que tanto a altura do sensor sob a superfície do solo como a carência de ventilação são fatores adicionais de erro quando se trabalha com o método de balanço de calor em casa de vegetação.

Simulações numéricas foram feitas por Baker \& Nieber (1989), van Bavel \& McInnes (1991) e Groot \& King (1992), ao discutirem as fontes teóricas de erros do método, concluíram que tais erros são aceitáveis para fins práticos, desde que sejam tomadas as precauções na construção do sensor e na interpretação dos dados; sem esses cuidados, erros substanciais podem ocorrer, principalmente quando o fluxo de seiva é pequeno, o armazenamento do calor no segmento de tronco é grande e são mínimas as diferenças de temperatura acima e abaixo do segmento do caule aquecido (Shackel et al., 1992).

Esses problemas foram detectados por Valancogne (s/d) e minimizados através da medida do armazenamento do calor e da instalação ligeiramente assimétrica das sondas de temperatura mais próximas à fonte aquecedora em relação aos limites superior e inferior do segmento de tronco.

Weibel \& de Vos (1994) fizeram medidas em macieira com sensor comercial, encontrando erros superiores a $20 \%$ na estimativa do fluxo diário de seiva, decorrentes da falta de bom contato entre o sensor e o tronco, e de danos causados a este 
pelo fornecimento contínuo de calor durante um período superior a 6 dias, além da desuniformidade da distribuição espacial do fluxo de seiva, que exige medida de temperatura em todas as direçōes no segmento de tronco. Verificaram, também, que o sensor mostrou atraso de resposta considerável em períodos de rápidas variações transpiratórias, principalmente pela falta de estimativa da energia armazenada pelo caule; para minimizar esses erros, o sensor foi aperfeiçoado, obtendo-se diferenças inferiores a $4 \%$ no período diumo e $15 \%$ na escala de 15 a 30 minutos, entre os valores estimados e medidos de transpiração.

A quantificação da condutividade térmica do caule $\left(\mathrm{K}_{c}\right)$ é bastante problemática e difícil de ser feita, usando-se como valores $0,54 \mathrm{~W} \mathrm{~m}^{-1}{ }^{\circ} \mathrm{K}^{-1}$ (Sakuratani, 1981) em herbáceas e $0,42 \mathrm{~W} \mathrm{~m}^{-1}{ }^{\circ} \mathrm{K}^{-1}$ (Steinberg et al., 1989) em lenhosas. Entretanto, a condutividade térmica do caule depende do volume do segmento aquecido como da capacidade térmica volumétrica, que por sua vez depende das frações volumétricas de água e celulose (Serway, 1986). A esse respeito, Chandra et al. (1994) e Weibel \& de Vos (1994), sugerem que essa propriedade pode variar com a porosidade e conteúdo de umidade da madeira.

Peressotti \& Ham (1996) postulam que, embora o fluxo de calor conduzido verticalmente durante o período luminoso seja relativamaente baixo quando comparado com o fluxo convectivo, em certas circunstâncias, pequenos erros no uso de $\mathrm{K}_{c}$ levam a grandes erros nas estimativas dos fluxos de seiva, podendo levar também a erros na estimativa da constante de transferência de calor Ksh do fluxímetro medidor do fluxo 
radial de calor $\left(Q_{\mathrm{r}}\right)$. Segundo Senock \& Ham (1993), incrementos de até $30 \%$ podem ocorrer no transcurso do dia nos valores de "Ksh", devido à reduções na disponibilidade hídrica do solo; assim, flutuações no conteúdo hídrico da planta podem alterar as proporções volumétricas de água e celulose no caule, com efeitos diretos nas propriedades térmicas e na estimativa de "Ksh", pela alteração dos fluxos axiais de calor (Qv) e da resultante estimativa de "Qr".

Shackel et al. (1992), Gutierrez et al. (1994) e Gerdes et al. (1994), demonstraram que as condições ambientais podem induzir gradientes de temperatura no interior do sensor, causando erros substanciais nas medidas dos fluxos de calor, em condições de campo. Steinberg et al. (1989) indicam que pequenos erros $(<10 \%)$ na estimativa dos fluxos são produzidos por grandes erros $(>10 \%)$ dos valores de Ksh durante altos fluxos. Assim, assumir um só valor de $\mathrm{K}_{\mathrm{c}}$ e de Ksh pode causar erros substanciais na estimação dos fluxos de calor.

Para sensores convencionais, com um só elemento, Ishida et al. (1991) demonstraram que podem ser operados com sistemas de potência elétrica de compensação variável, para manter temperaturas definidas (controladas) dentro do sensor, eliminando assim o problema de superaquecimento do caule. Kitano \& Eguchi (1988) usaram 3 resistências e 3 reguladores de potência para manter constantes os fluxos componentes nos sentidos axial e radial, negligenciando esses componentes do balanço de calor e eliminando a necessidade das medições dinâmicas das temperaturas verticais e radiais. Porém, os 
sensores operando com um só elemento aquecedor, têm que ser calibrados em condições de equilíbrio dinâmico e exigem a quantificação dos valores de Qv e Qr.

Chandra et al. (1994) descrevem um sensor com elementos aquecedores múltiplos, em que duas resistências envolvem o caule e uma terceira envolve as anteriores. As duas primeiras são operadas em paralelo e reguladas para manter constante a diferença de temperatura da seiva entre as secçōes retas superior e inferior do segmento de caule aquecido; a terceira é controlada para eliminar os gradientes radiais e remover o fluxo radial (Qr) do balanço de calor. Mediante esta aproximação, o fluxo pode ser calculado somente a partir da potência aplicada; infelizmente, esta técnica negligencia a influência dos fluxos verticais $(\mathrm{Qv})$, que podem ser significantes durante baixos fluxos de seiva, principalmente em plantas pequenas (Senock \& Ham, 1993). Adicionalmente, Chandra et al. (1994) concluiram que a técnica pode fracassar em determinadas situações, principalmente em condições em que o fluxo radial é em direção ao caule, porque o elemento aquecedor teria que funcionar como resfriador.

Peressotti \& Ham (1996) propuseram um novo tipo de sensor duplo que não requer calibração empírica e não provoca danos ao caule por superaquecimento, que quantifica os fluxos de dissipação do balanço de calor em dois segmentos adjacentes do caule e mediante relação dos dois balanços, desenvolvendo a equação para quantificar o fluxo sem requerimento do controle de Qr. 


\section{MATERIAL E MÉTODOS}

\subsection{Teoria do método}

As considerações teóricas para o método de balanço de calor são baseadas nas técnicas de medidas de fluxo térmico introduzidas por Thomas (1911), para medir fluxo de gases, mediante a aplicação de calor. A aplicação dessas técnicas em plantas e a discussão das equações matemáticas foram desenvolvidas originalmente por Sakuratani $(1981,1984)$ e Baker \& van Bavel (1987).

O método usa os conceitos de balanço de energia para monitorar os fluxos de calor dentro de um segmento de caule ao qual é fomecida uma taxa constante de calor. Sendo todo o sistema isolado termicamente do exterior, o balanço energético em termos dos diferentes fluxos caloríficos é representado na figura 1 e definido pela equação 1 . 


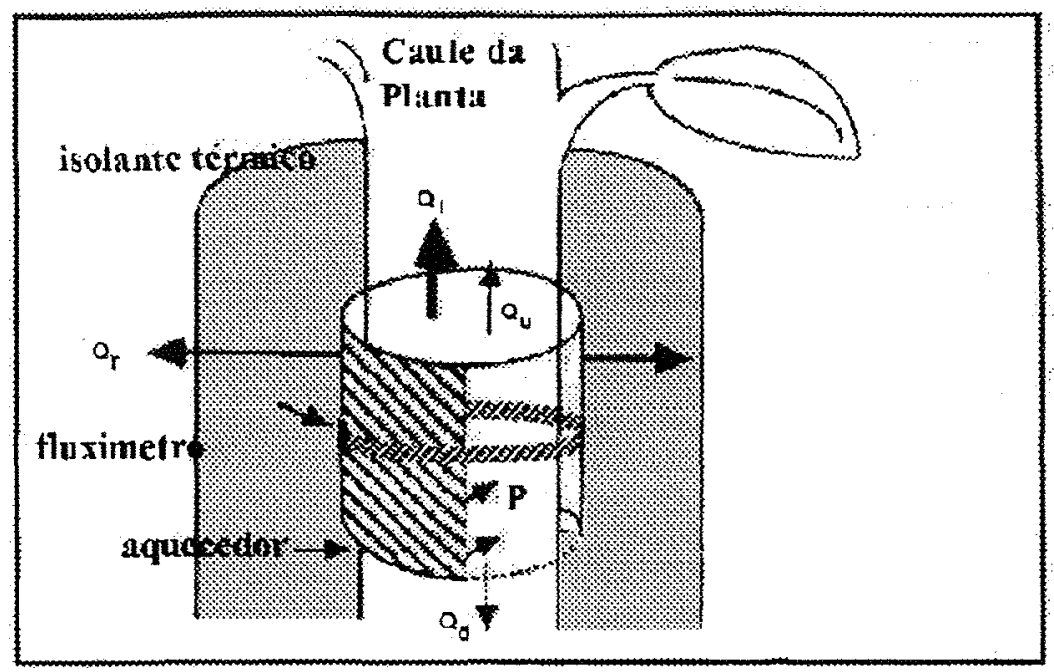

Figura 1 - Esquematização dos fluxos no método de balanço de calor.

$$
P=Q_{u}+Q_{d}+Q_{r}+Q_{f}+Q_{s}
$$

sendo que $\mathrm{P}$ é a potência aplicada, $\mathrm{Q}_{u}$ e $\mathrm{Q}_{d}$ representam os fluxos de calor transferidos por condução (apical ou basal) ao longo do eixo do caule, $Q_{r}$ é a condução radial de energia perpendicularmente ao eixo do caule, $\mathrm{Q}_{\mathrm{F}}$ é a energia transportada convectivamente por fluxo de massa e $\mathrm{Q}_{s}$ é a taxa de variação de calor armazenada pelo segmento aquecido; todos os componentes são expressos em watts (W).

A quantidade de calor aplicada ao caule pode ser calculada conhecendose a diferença de potencial elétrico em volts (V) e a resistência elétrica em ohm $(\Omega)$ do elemento dissipador, conforme representado pela equação 6.

$$
P=V^{2} / R
$$


Os fluxos condutivos ao longo do eixo do caule no sentido ascendente $\left(\mathrm{Q}_{\downarrow}\right)$ e descendente $\left(\mathrm{Q}_{\searrow}\right)$ para fora dos limites do segmento aquecido, podem ser estimados a partir da equação de Fourier:

$$
\begin{aligned}
Q u & =K c \cdot A \cdot\left(\frac{d T u}{\Delta x}\right) \\
\mathrm{Q}_{\mathrm{d}} & =\mathrm{K}_{\mathrm{c}} \cdot \mathrm{A} \cdot\left(\frac{\mathrm{dTd}}{\Delta \mathrm{x}}\right)
\end{aligned}
$$

sendo que $\mathrm{K}_{\mathrm{c}}$ é a condutividade térmica do caule $\left(\mathrm{W} \mathrm{m}^{-1}{ }^{\circ} \mathrm{K}^{-1}\right)$, A a área da secção transversal do caule $\left(\mathrm{m}^{2}\right)$ e $(\mathrm{dTu} / \Delta \mathrm{x})$ e $(\mathrm{dTd} / \Delta \mathrm{x})$ são gradientes de temperatura $\left({ }^{\circ} \mathrm{K} \mathrm{m} \mathrm{m}^{-1}\right)$ nos limites superior e inferior do segmento de caule, respectivamente. A condutividade térmica do caule $K_{c}$ pode ser obtida usando o método descrito por Sakuratani (1979), sendo necessário conhecer os valores da condutividade térmica dos componentes que compõem o caule, isto é, madeira, ar e água (Km, Kar, Kágua) e suas respectivas frações volumétricas (Vm, Var, Vágua), conforme representado matematicamente sob a forma da equação (9).

$$
\mathrm{K}_{\mathrm{c}}=\mathrm{Km} \cdot \mathrm{Vm}+\mathrm{Kar} \cdot \mathrm{Var}+\mathrm{K} \text { agua } \cdot \mathrm{V} \text { agua }
$$

O fluxo de calor perpendicular ao eixo do caule, através do isolante que envolve a resistência $\left(Q_{r}\right)$ é estimado aravés da determinação do coeficiente de transferência de calor do fluxímetro (Ksh) em W. $\mathrm{mV}^{-1}$ e a força eletromotriz (E) em $\mathrm{mV}$, gerada pela diferença de temperatura entre a face externa e intema da lâmina do material 
com o qual é construido o fluxímetro. O fluxo é estimado pela equação (10), que é a forma integrada da equação do fluxo radial de calor $\left(Q_{r}\right)$ em um cilindro de comprimento infinito (Incropera \& Dewitt, 1990):

$$
Q_{r}=\frac{2 \pi K_{c o} L(T i-T o)}{\ln \left(r_{i} / r_{o}\right)}
$$

onde $\mathrm{K}_{\infty}$ é a condutividade térmica do material isolante constituinte do fluxímetro (W. $\mathrm{m}^{-1}$. ${ }^{\circ} \mathrm{K}^{-1}$ ), L é o comprimento do segmento aquecido (m), Ti é a temperatura na superfície interna, medida dentro do isolante $\left({ }^{\circ} \mathrm{K}\right)$, To é a temperatura externa $\left({ }^{\circ} \mathrm{K}\right), \mathrm{r}_{\mathrm{i}}$ é o raio da superfície interna do isolante $(\mathrm{m})$ e $\mathrm{r}_{\mathrm{o}}$ é o raio da superfície externa do isolante $(\mathrm{m})$. Como todos os parâmetros da equação (10) são constantes para uma configuração determinada, podem ser combinados com um único fator de conversão relacionado com a força eletromotriz (E) gerada pelo fluxímetro, pela diferença de temperaturas ( $\mathrm{Ti}$ - To) e definido como coeficiente de transferência de calor do fluxímetro "Ksh", com unidades em W. $\mathrm{mV}^{-1}$. A equação (6) pode ser transformada na seguinte equivalente:

$$
Q,=K s h \cdot E
$$

$\mathrm{E}=$ diferença de temperatura na face interna e externa do fluxímetro Ksh - condutividade térmica do material constituinte do fluximetro 
Valores de Ksh são estimados em condições de fluxo de seiva zero $\left(\mathrm{Q}_{\mathrm{f}}=\right.$ 0) e estimando-se nessas condições, o valor de $\mathrm{Q}_{r}$. Com a medida simultânea de E, estimase Ksh. Fluxos de seiva nulos são obtidos em segmentos cortados de caule (Baker \& van Bavel, 1987) ou usando os sinais noturnos emitidos pelo sensor, quando se assume estar ocorrendo fluxo de seiva nulo (Steinberg et al., 1989).

$\mathrm{O}$ valor de $\mathrm{Q}_{\mathrm{s}}$ é desprezado, assumindo-se que há equilíbrio dinâmico no sistema, principalmente em plantas herbáceas, porque a magnitude de $\mathrm{Q}_{s}$ é pequena quando comparada com os demais componentes da equação (5). Para plantas lenhosas, entretanto, têm sido demonstrado que esse componente não pode ser desprezado e seu valor pode ser estimado usando-se a equação (12):

$$
Q_{s}=C_{v} \cdot A \cdot L \cdot\left(\frac{d T}{d t}\right)
$$

em que $\mathrm{C}_{\mathrm{v}}$ é a capacidade térmica volumétrica do caule $\left(\mathrm{J} \mathrm{m}^{-3} \mathrm{~K}^{-1}\right)$, A a área da sua secção transversal $\left(\mathrm{m}^{2}\right)$, L é o comprimento do segmento aquecido $(\mathrm{m})$ e (dT/dt) é a taxa de variação da temperatura $\left(\mathrm{Ks}^{-1}\right)$.

Conhecido esses componentes de balanço de calor, o componente fluxo convectivo de calor transportado pela seiva $\left(\mathrm{Q}_{\mathrm{f}}\right)$ pode ser estimado como termo residual e relacionado ao fluxo de massa de seiva pela equação: 


$$
\text { Qf }=C p \cdot F \cdot\left(d T_{u d}\right)
$$

em que: $\mathrm{C}_{\mathrm{p}}$ é o calor específico da seiva $\left(\mathrm{J} \mathrm{kg}^{-1} \mathrm{~K}^{-1}\right)$, F é a taxa de fluxo de água $\left(\mathrm{kg} \mathrm{s}^{-1}\right)$ e dtud é a diferença de temperatura nas seç̧ōes retas superior e inferior do segmento de caule aquecido, representando o aquecimento da seiva durante sua passagem por essa parte do caule.

Substituindo a equação (13) na equação (5) e denominando $Q_{u}+Q_{d}=$ $\mathrm{Q}_{v}$, obtém-se uma equação geral do fluxo de massa de seiva para o segmento aquecido:

$$
F=\frac{P-Q_{v}-Q_{r}-Q_{s}}{C_{p} \cdot\left(d T_{u d}\right)}
$$

\subsection{Montagem dos sensores}

Os componentes individuais dos sensores usados em milho e citros são similares ao descrito por Baker \& Van Bavel (1987) e Steinberg et al. (1989). O elemento dissipador de calor era constituído de resistor de constantan, de diâmetro 0,127 mm (AWG $\mathrm{n}^{0} 36$ ), tendo comprimento igual à circunferência e altura igual a 1,5 vez ao diâmetro do caule, segundo as recomendaçōes de Sakuratani (1981) e Ham \& Heilman (1990). Uma fina lâmina de alumínio com as mesmas dimensōes foi colocada em ambos os lados do resistor, para assegurar aquecimento uniforme. Nas extremidades do segmento de caule aquecido foram instalados 8 termopares de cobre-constantan igualmente espaçados e 
ligados em paralelo com os outros, de maneira que a tensão de saída representasse a média aritmética dos 4 pares (Steinberg \& van Bavel, 1989), localizados $5 \mathrm{~mm}$ acima e $8 \mathrm{~mm}$ abaixo da jaqueta térmica; a distância vertical entre os termopares foi de $4 \mathrm{~mm}$. Sobre o elemento dissipador, foi instalado um fluxímetro para medidas de fluxo radial de calor, constituído de 8 termopares ligados em série sobre uma placa de cortiça, sendo 4 em cada lado desta. Uma lâmina de politetrafluoretileno era colocada entre a placa de alumínio e o fluxímetro, para evitar contato direto dos termopares com a lâmina de alumínio. Todos esses elementos foram montados sobre uma lâmina de cortiça de $2 \mathrm{~mm}$ de espessura reforçada com adesivo à base de borracha natural e verniz, que foi o suporte flexível, sendo o conjunto encapsulado em cilindro isolante de isopreno com $17 \mathrm{~mm}$ de espessura (Figura 2).

No caso do tomate, o elemento dissipador de calor tinha comprimento igual à circunferência e a altura igual à duas vezes o diâmetro do caule. Os pares de termojunções, instalados nas extremidades do segmento aquecido, foram instalados a $2 \mathrm{~mm}$ acima e a $5 \mathrm{~mm}$ abaixo da jaqueta térmica; a distância vertical entre as termojunções foi de $3 \mathrm{~mm}$. O fluxímetro lateral foi montado com 3 termopares em cada lado da placa de cortiça; a espessura do isolante térmico foi de $7 \mathrm{~mm}$.

A figura 3 mostra detalhes da construção do sensor e uma vista geral de sua instalação em tomateiro, junto com a balança e o sistema de aquisição de dados. 


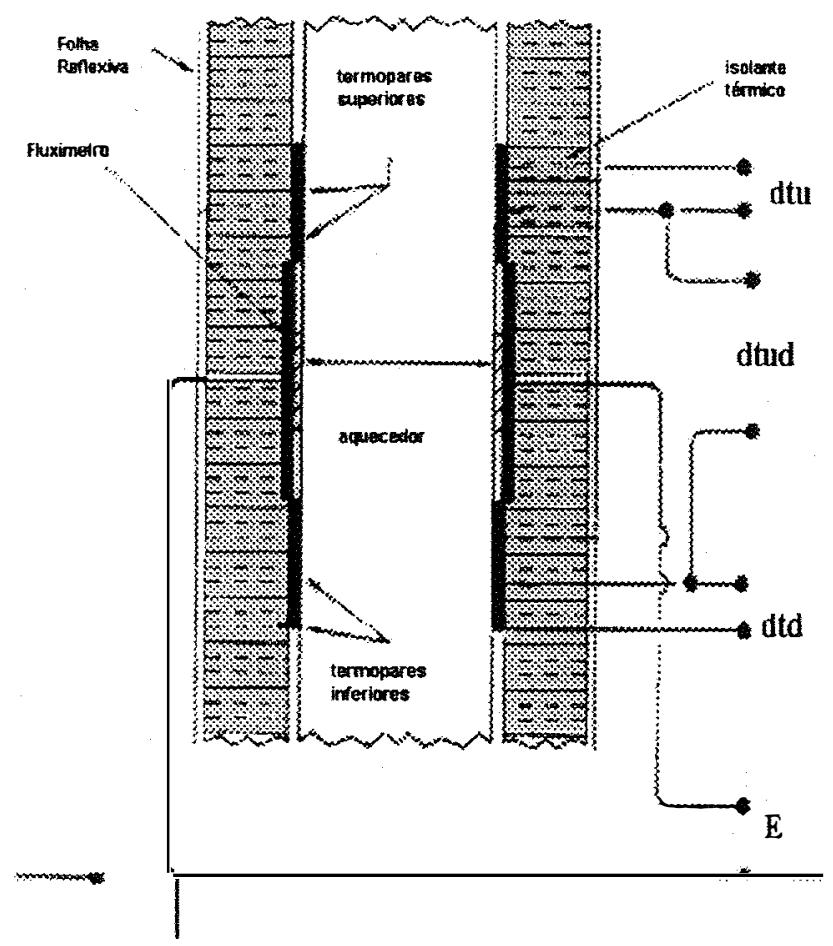

Figura 2 - Esquema do sensor de medida (adaptado de Steinberg et al., 1989).

\subsection{Plantas utilizadas}

\subsubsection{Herbáceas}

Sementes de milho (híbrido simples AG-9014) cedidas pelo Departamento de Genética da ESALQ/USP e de tomate (cultivar Ângela Gigante I-5100), obtidas no comércio local, foram semeadas em vasos plásticos com capacidade para 5 kilogramas, contendo solo e uma mistura comercial à base de vermiculita e de material orgânico na relaçäo de 4:1 em volume. Em dois períulus diferenties com espaço de 20 dias, 7 dias 


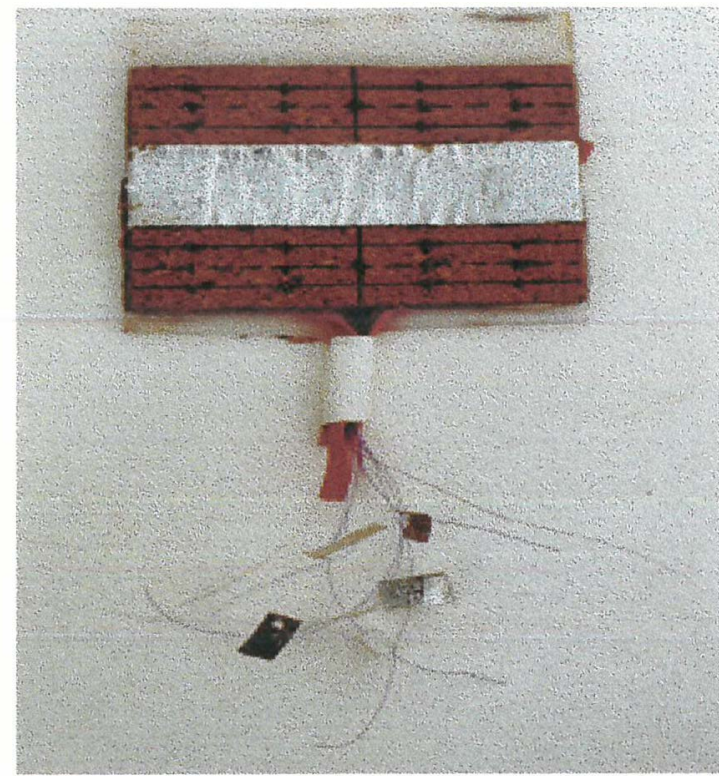

A

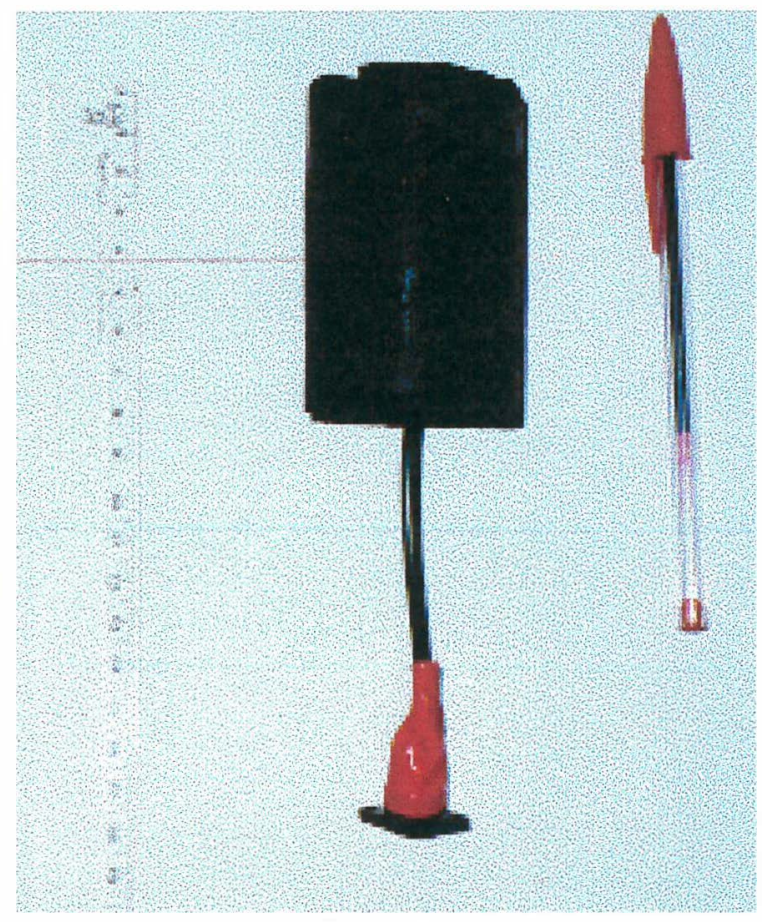

C

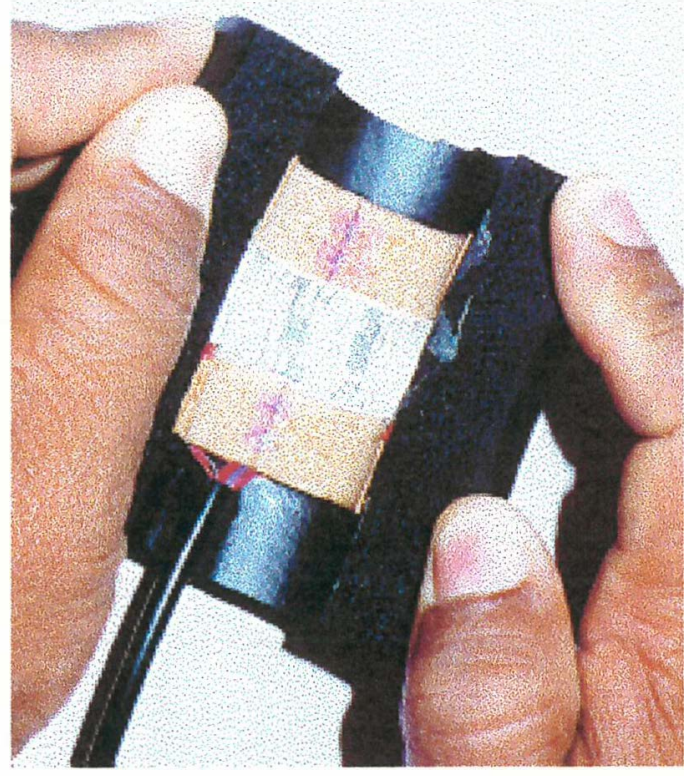

B

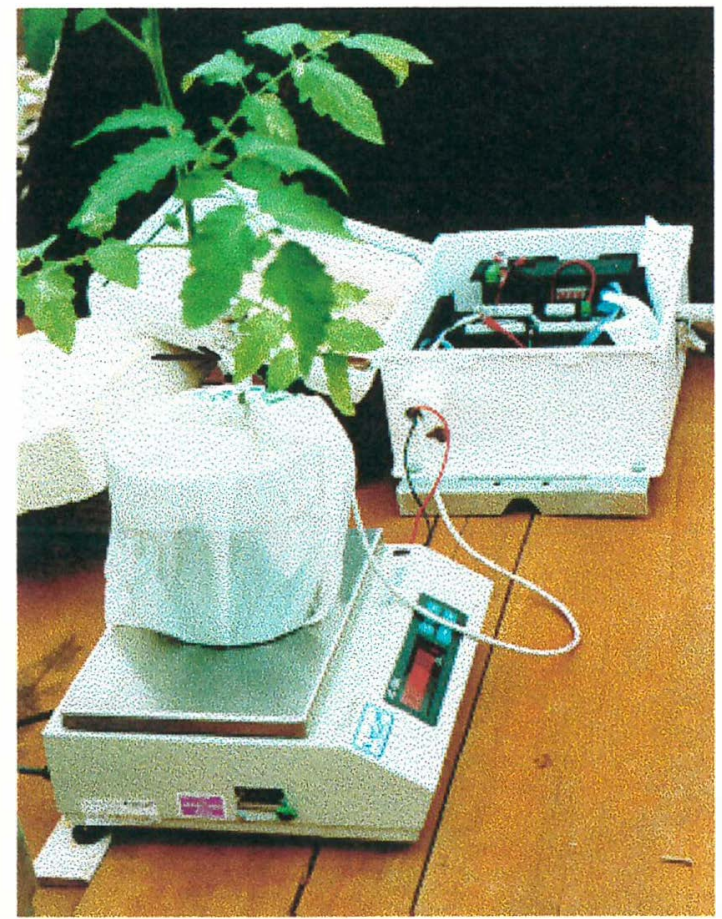

D

Figura 3. Detalhes construtivos do sensor: A) Sensor sem o isolante térmico, vendo-se o elemento dissipador de calor e as junções dos termopares; a termopilha encontra-se sob o elemento dissipador, não sendo vista; B) vista do sensor aberto,com isolante térmico; C) vista do sensor fechado, com o conector; D) vista geral da montagem em tomateiro, sendo que a seta indica a posição do sensor na planta. 
após a emergência, foi feito o desbaste deixando-se 1 planta por vaso. No caso do tomate, foi realizado um segundo desbaste 14 dias após a emergência, deixando 1 planta por vaso. As plantas eram irrigadas diariamente e fertilizadas a cada 14 dias, com solução nutritiva completa. Assim, foram mantidas crescendo sob condições de temperatura e radiação solar de casa de vegetação. Uma vez que atingiram o diâmetro apropriado, foram selecionadas para os testes de medição aproximadamente aos 35 dias após a emergência.

\subsubsection{Lenhosas}

Mudas de limoeiro "Tahiti", com diâmetros em torno de $18 \mathrm{~mm}$ e com área foliar relativamente uniforme, adquiridas de viveirista, foram transplantadas para vasos plásticos com capacidade de $50 \mathrm{~kg}$, contendo uma mistura de solo e produto comercial denominado "substrato", à base de vermiculita e material orgânico na relação de 4:1 em volume. Após mantidas sob condições normais de temperatura e radiação solar de casa de vegetação por um período de 20 dias para adaptação, eram selecionadas para os testes.

\subsection{Procedimentos dos testes}

Vários sensores foram construídos e testados nas diferentes espécies de plantas em casá de vegetação. Antes dos testes, os vasos eram irrigados até a saturação e 
deixados a drenar por 20 minutos, sendo então selados com papel alumínio na parte superior e colocados em embalagem plástica, visando evitar a evaporação pelo solo. Antes da instrumentação da planta, o caule era lavado com algodão umedecido em solução alcoólica $60 \%$, sendo que no caso de citros, o tecido suberoso era parcialmente eliminado com lixa fina $n^{0} 21$. Após, era colocada uma película de silicone dielétrico (G-3) e o sensor instalado e completamente coberto com uma folha refletiva de papel aluminizado.

O vaso com o sistema de medida era colocado sobre uma balança eletrônica, marca AC-10K ART-Lab, com capacidade de 10 kilogramas e sensibilidade de 0,01 g (milho e tomate); para citros, os vasos foram colocados sobre uma balança modelo LC-50 Marte, com capacidade de $50 \mathrm{~kg}$ e sensibilidade de $10 \mathrm{~g}$. O resistor dissipador de calor era alimentado por uma fonte de corrente contínua (Ps-30002D, Ddawer) e a tensão elétrica foi regulada de acordo com o valor das resistências. Os sinais dos sensores foram registrados cada segundo por um sistema de aquisição de dados (CR-7, Campbell Scientific Ltd., Logan, Utah, USA) e armazenados a cada 30 minutos. Para cada planta, as medidas foram feitas por 3 dias consecutivos, substituindo-se a água perdida diariamente às 18:00 horas. No quarto dia, eram realizados testes da resposta dinâmica do sensor e em seguida, as folhas eram destacadas e determinada a área foliar, com medidor de área (LI-3100, Licor Inc., Lincoln, Nebraska, USA). 


\subsection{Testes de resposta dinâmica}

A resposta dinâmica dos sensores foi avaliada determinando-se a constante de tempo, de acordo com o descrito por Kucera et al. (1977), utilizando-se a

$$
t_{c}=\frac{\left(m_{s} \cdot C_{p s}\right)}{\left(F \cdot C_{p, w}+L_{s}\right)}
$$

equação:

em que $t_{c}$ é a constante de tempo (seg), $m_{8}$ é a massa do segmento aquecido $(\mathrm{kg}), \mathrm{C}_{\mathrm{P}_{\mathrm{s}}}$ é a capacidade calorífica do segmento $\left(\mathrm{J} \mathrm{Kg}^{-1} \mathrm{~K}^{-1}\right)$, F é o fluxo de seiva $\left(\mathrm{kg} \mathrm{s}^{-1}\right), \mathrm{C}_{\mathrm{P} . \mathrm{w}}$ é o calor específico da seiva $\left(\mathrm{J} \mathrm{kg}^{-1} \mathrm{~K}^{-1}\right)$ e $\mathrm{L}_{\mathrm{s}}$ é a condutância calorífica do sistema ( $\left.\mathrm{W} \mathrm{K}^{-1}\right)$. Uma súbita mudança no fluxo foi provocada pela decapitação da planta imediatamente acima do sensor, num momento de alto fluxo e calculando o tempo requerido para que o sensor registrasse uma redução de $63 \%$ na sua resposta. A análise de regressão dos logarítmos naturais das variaçōes dos valores aparentes de fluxo após eliminação do fluxo real em função do tempo, foi usada para estimar a constante de tempo, definida pelo recíproco do coeficiente angular da reta de regressão (Baker \& Van Bavel, 1987; Senock \& Ham, 1993). 


\section{RESULTADOS E DISCUSSÃO}

\subsection{Comparação das estimativas de fluxo de seiva pelo método de balanço de calor com as medidas de transpiração por pesagem}

\subsubsection{Herbáceas}

As figuras 4a e 4b apresentam um exemplo das variaçōes dos fluxos de seiva estimados pelo método de balanço de calor (MBC) em comparação com a taxa transpiratória medida gravimetricamente ao longo de periodos subsequentes de 3 dias, em plantas de tomate e milho respectivamente. 

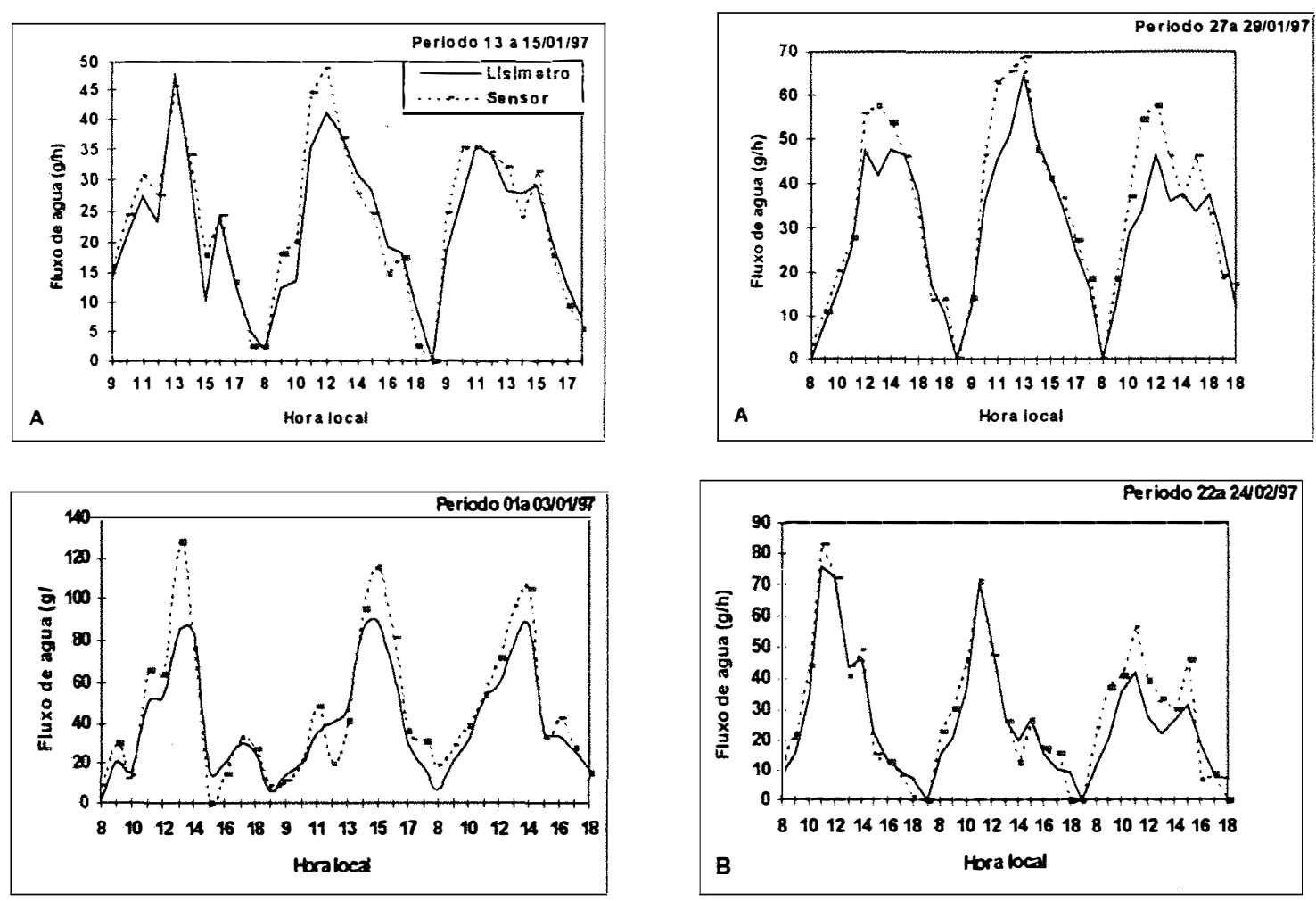

Figura 4 - Comparação dos fluxos de água medidos gravimetricamente e estimados pelo método de balanço de calor em períodos subsequentes de 3 dias. A Tomate; B. Milho.

Observa-se uma boa aderência entre as duas curvas nas horas da manhã quando o fluxo transpiratório é relativamente baixo. Entretanto, quando a transpiração incrementa ou flutua rapidamente a curva do fluxo de seiva se desvia da transpiração, como pode ser observado no segundo dia do primeiro período e primeiro e terceiro dia de segundo período (Figura 4a) e no terceiro dia do primeiro período e durante ou segundo período (Figura 4b) em tomate e milho respectivamente, principalmente nas horas de maior demanda hídrica. 
Os desvios podem refletir tanto erros de estimativa e/ou uma realidade do transporte hídrico na planta, pois a perda de água na fase de vapor em intervalos de tempo curtos, na escala horária por exemplo, não necessita ser igual ao fluxo de seiva na altura da planta onde o sensor foi instalado. Isto somente ocorreria se houvesse condições de perfeito equilibrio dinâmico no transporte hídrico ao longo do sistema solo-plantaatmosfera. Em momentos de alta demanda hídrica da atmosfera, pode ocorrer uma diminuição da condutância estomática à difusão de vapor, com a conseqüente redução da transpiração, sem a concomitante diminuição do fluxo de seiva, que ocorre em função do gradiente hidráulico no interior da planta. Em uma fase posterior a essa. Com a diminuição do fluxo na fase de vapor e conseqüente diminuição do gradiente hidráulico, o fluxo de seiva diminui posteriormente, podendo atingir valores inferiores ou não aos da transpiração no período da tarde, conforme alguns dias mostrados na Figura 3. Entretanto, na parte da manhã o que tem sido verificado por outros autores, tanto em herbáceas como em lenhosas, é uma tendência de maior fluxo de ranspiração em relação à absorção de água nas raízes (Kramer, 1983) ou ao fluxo de seiva no caule (Valancogne \& Nasr, 1989), inversa ao observado neste trabalho.

Esse padrão descrito no qual a transpiração supera o fluxo de seiva no período da manhã é o que se espera em dias de alta demanda, sendo que parte da água transpirada é retirada dos próprios tecidos, que por isso tem seu armazenamento hídrico diminuido, levando à diminuição do seu potencial da água. A partir de uma parte do período diumo e principalmente à noite, com redução drástica do fluxo de transpiração, ocorre rearmazenamento hídrico no tecido se a disponibilidade hídrica no solo é adequada. 
Assim, pode-se supor que a estimativa de fluxos de seiva maiores que de transpiração no período matutino seja causado por uma fonte de erro no método de balanço de calor. Para se ter uma visualização mais global do desempenho do MBC, a Figura 5 mostra as correlações entre fluxo de seiva e de transpiração na escala horária, com forçamento da passagem da reta pela origem dos eixos.
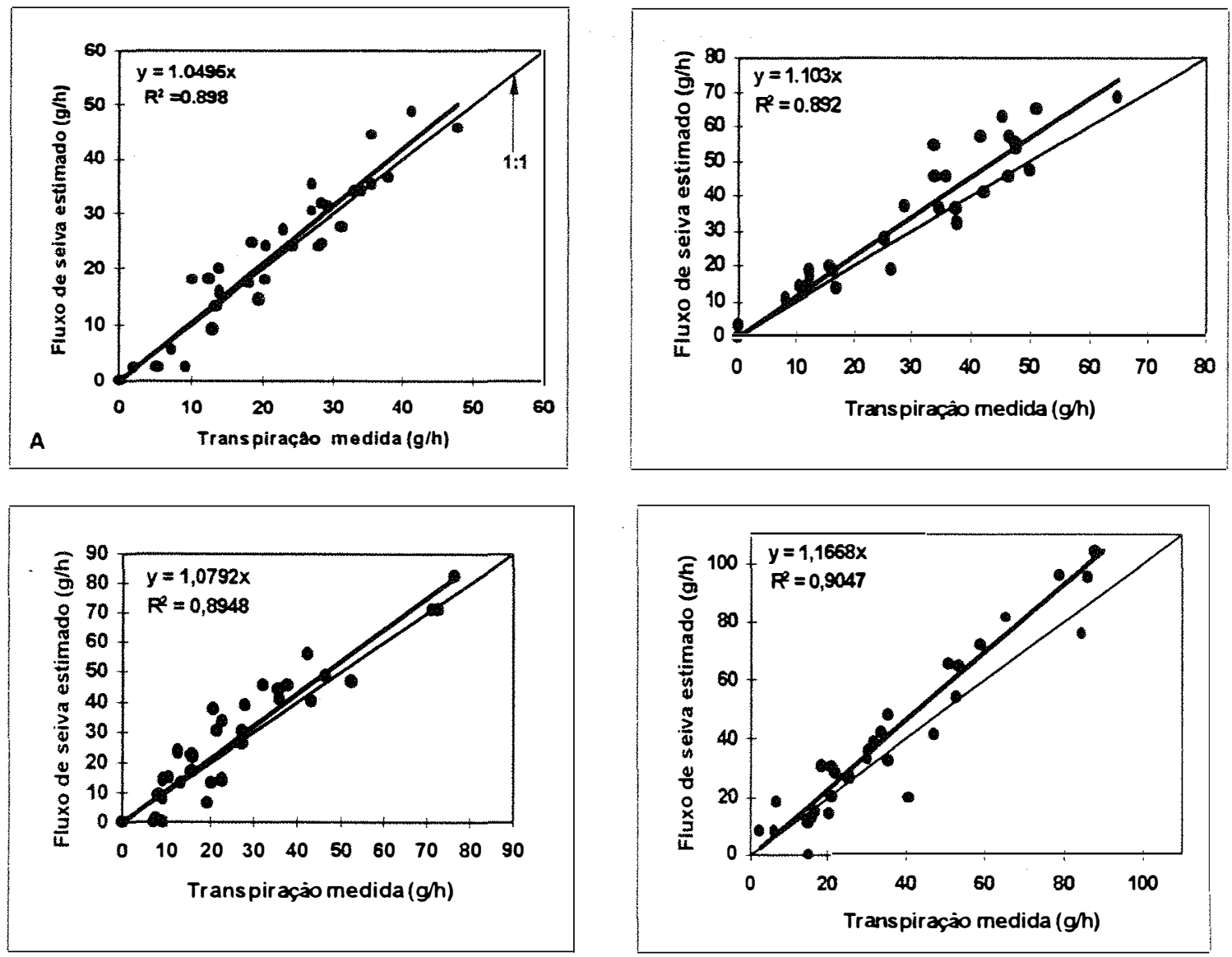

Figura 5 - Fluxos acumulados durante dois periodos sequenciais de 3 dias, na escala horária, A. Tomate; B. Milho. 
Verifica-se os altos coeficientes de determinação de tomate $\left(\mathrm{R}^{2}=0,89\right)$ e em milho $\left(\mathrm{R}^{2}=0,89\right.$ e 0,90$)$. Em termos médios, o fluxo de seiva estimado pela $\mathrm{MBC}$, tendeu a apresentar valores 4 a $10 \%$ maiores que o de transpiração em tomateiro e 7 a $16 \%$ em plantas de milho, embora tenham sido registradas em alguns horários, diferenças de até $36 \%$ entre os dois tipos de fluxo.

A correlação entre os fluxos acumulados determinados pelos dois métodos na escala horária como na escala diária (8 às 18 hs) em 12 dias é mostrada na Figura 6.

Durante o período noturno, os valores de fluxo de seiva estimados foram muito pequenos e muitas vezes negativos indicando fonte de erro devido à sensibilidade do sensor não ser suficiente para detectar fluxos próximos de 0. Para fins de uniformização de tratamento adotou-se o valor acumulado das 8 as 18 horas como representativo da escala diária, embora em muitos dias tivessem sido estimados valores positivos a partir de 7 horas e entre 18 e 19 horas, principalmente em dias longos.

Na escala horária observa-se uma maior dispersão dos dados; sendo mais pronunciada em milho principalmente quando os fluxos de seiva foram superiores a $80 \mathrm{~g} \mathrm{~h}^{-1}$; embora a correlação seja alta em ambas espécies, em média os fluxos de seiva foram maiores que a transpiração em 8 e $15 \%$ na escala horária para tomate e milho respectivamente. Já na escala diária a dispersão é pequena mas os fluxos de seiva excedem em média 8 e $13 \%$ a taxa transpiratória registrada durante o período das 8 às 18 horas. 

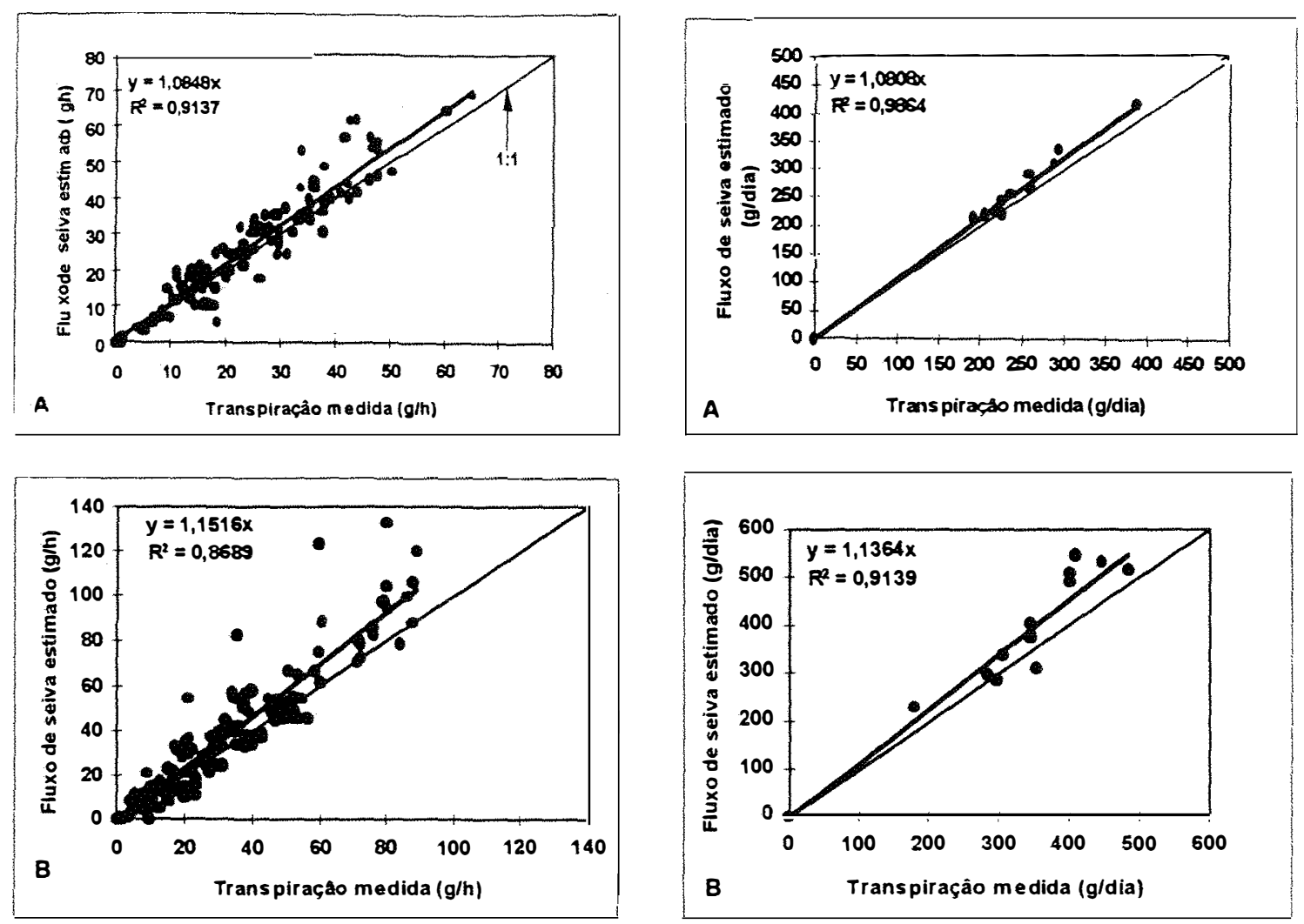

Figura 6 - Comparação do fluxo de seiva e da transpiração durante um período de 12 dias, na escala horária e na escala diária. A Tomate; B. Milho.

A diminuição da diferença percentual das medidas na escala de 10 horas é devida à compensação de erros ao se fazer a somatória dos valores horários. A tendência de superestimativa do método de balanço de calor na escala de 10 horas é devido ao fato do fluxo de seiva estimado ter sido maior no período matutino e ao meio do dia. Como já descrito, a tendência matưina não é explicável fisiologicamente e deve ser decorrente de erro no método. Nesse caso, uma hipótese pode ser a desconsideração do termo de 
armazenamento de calor $\left(\mathrm{Q}_{S}\right)$ no balanço. No caso das herbáceas estudadas, não foram feitas para determinar a magnitude desse componente no balanço, por supô-lo desprezível em plantas de pequeno porte, de acordo com o encontrado na literatura. Entretanto, observações em limoeiro descritas no ítem 3 mostram que pelo menos nessa lenhosa, para plantas de pequeno porte, esse termo pode ser desprezado. Esse pode ser o caso do tomateiro e do milho usados, mas para se concluir sobre a importância do termo $Q_{S}$, há necessidade de estudos adicionais.

Por outro lado, superestimativas de fluxo de seiva durante altas taxas transpiratórias são reportadas por vários outros autores em girassol (Ham \& Heilman, 1990; Zhang \& Kirkham, 1995), em milho (Ishida et al., 1991; Cohen et al., 1993) em soja (Gerdes et al.) e em diversas herbáceas (Stockle et al., 1991).

A taxa transpiratória máxima registrada em plantas de tomate foi de $65 \mathrm{~g} \mathrm{~h}^{-1}$, em milho estas taxas foram superiores a $80 \mathrm{~g} \mathrm{~h}^{-1}$ (Figura 3). Como pode ser observado, os maiores desvios entre os fluxos de seiva e a transpiração ocorreram quando esta foi superior a $50 \mathrm{~g} \mathrm{~h}^{-1}$, o que pode ser devido à falta de equilíbrio térmico entre a superfície externa do caule e a seiva em movimento, resultando numa representação inadequada das variações de temperatura na secção transversal do caule quando ela é medida sobre a superfície do mesmo, como observado por Ishida (1991) e Cohen et al. (1993). Baker \& Nieber (1989), mediante simulações numéricas de distribuição térmica, mostraram que erros nas medidas são mais prováveis durante altos fluxos de seiva pela pequena magnitude dos gradientes térmicos nâ seção transversal e os fortes gradientes na 
superfície externa do caule próxima ao aquecedor, provocando erros no fluxo computado, como foi posteriormente evidenciado por Ham \& Heilman (1990), que observaram uma drástica superestimativa dos fluxos de seiva quando estas foram superiores a $90 \mathrm{~g} \mathrm{~h}^{-1} \mathrm{em}$ plantas de girassol, atribuindo isto aos baixos valores de "dTud", e ao aquecimento da superfície do caule pelas condições ambientais. A variação na potência aplicada não melhora o comportamento dos sensores quanto a esse aspecto. Stockle et al. (1991), avaliando a inserção ou não das termojunções no caule em diversas espécies de plantas herbáceas, reportam erros absolutos de $15 \%$ na estimação dos fluxos quando a temperatura é medida somente na superfície do caule e apenas $4,7 \%$ quando esta é medida na parte interna do caule $(2 \mathrm{~mm})$ na escala horária e para fluxos maiores de $40 \mathrm{~g} \mathrm{~h}^{-1}$.

A indicações de que o método apresentou melhor desempenho em tomateiro que em plantas de milho. Além da taxa de fluxo, a anatomia do sistema vascular parece ser muito importante no desempenho do método de balanço de calor. As dicotiledôneas por possuírem um sistema vascular contínuo envolvendo a medula e formando anéis no plano transversal (Essau, 1960), permitiriam um melhor contato entre o sistema vascular e o dissipador de calor, o que potencialmente as tornaria mais apropriadas para as medições do fluxo pelo método de balanço de calor (Ishida et al., 1991), possibilidade já anteriormente demonstrada por Baker \& Nieber (1989) mediante análises matemáticas. As monocotiledôneas possuem um sistema vascular distribuído ao acaso em toda a seção transversal e rodeado por bainhas esclerenquimáticas (Essau, 1960), permitindo uma maior variação da temperatura no caule nos sentidos radial e axial. 
dificultando o equilíbrio térnico principalmente quando os fluxos de seiva são altos devido às rápidas perdas de calor convectivo, como demonstrado teoricamente por Baker \& Nieber (1989) e evidenciado na prática por (Ishida et al., 1991; Cohen et al., 1993).

Cohen et al. (1993), mediante técnicas de infiltração, demonstraram que a estrutura do sistema vascular nas monocotiledôneas provocaram atraso no equilíbrio térmico entre a seiva que entra e a que sai do segmento aquecido, causando gradientes radiais que alterariam a estimação dos fluxos, atribuindo a esse fato as superestimativas de $25 \%$ nos fluxos obtidos em trabalho realizado com milho, concluindo que a assunção de que a temperatura na superfície do caule é equivalente à temperatura na seção transversal pode ser incorreta em condições de fluxos altos flutuantes, em plantas que têm um sistema vascular distribuído irregularmente no plano transversal do caule.
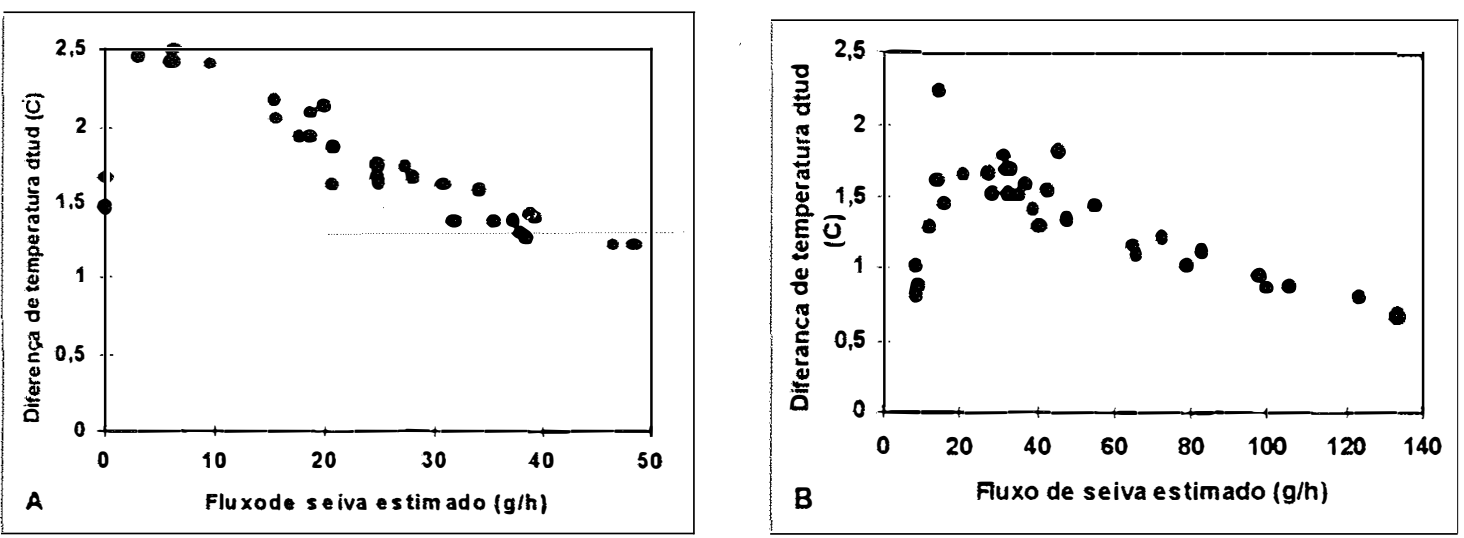

Figura 7 - Variação da diferença de temperatura entre as superfícies transversais do volume de caule com a variação do fluxo de seiva, para um período sequencial de 3 dias. A. tomate; B. Milho. 
As variações da temperatura do caule (valores de dTud) com as flutuações diárias dos fluxos de seiva para um período seqüencial de 3 dias são mostrados na Figura 6, apresentando a tendência típica da teoria do método, a qual indica que o valor de dTud inicialmente incrementa muito rápido até um máximo e logo tende a decrescer quando o fluxo continua aumentando (Van Bavel \& Van Bavel, 1990). As variações de diferença de temperatura na superfície do caule foram de 1,5 a $2,5^{\circ} \mathrm{C}$ em tomate e de 0,8 a $2,3^{\circ} \mathrm{C}$ em milho, contrastando com os resultados de alguma pesquisadores que reportam variações de 1 a $7^{\circ} \mathrm{C}$ (Steinberg et al., 1989; Groot \& King, 1992) em diversas espécies de lenhosas, e concordando com os resultados obtidos por Senock \& Ham (1993), Gerdes et al. (1994), Senock \& Ham, (1995) em diversas espécies herbáceas.

O fato de que dTud aumenta inicialmente com o aumento do fluxo de seiva, conduzindo a valores elevados à baixos valores de fluxo de seiva é, segundo Senock e Ham (1995), uma das razões de se ter medida com exatidão em caules pequenos; assim, a forma das curvas mostradas na Figura 7 é uma indicação de que a potência aplicada foi adequada. Neste estudo o valor da potência aplicada foi determinada, de maneira a se obter valores de dTud inferiores a $8^{\circ} \mathrm{C}$ nos períodos de baixos fluxos e superiores a $0,4^{\circ} \mathrm{C}$ durante os picos máximos de fluxo, como recomendado por Valancogne \& Nasr 1989; Van Bavel \& Van Bavel, 1990). 


\subsubsection{Lenhosas: Limoeiro}

As Figuras 8a e 8b apresentam o curso da transpiração ao longo do dia medida gravimetricamente e do fluxo de seiva estimado pelo método de balanço de calor para uma seqüência de dias com baixa e outra com alta demanda hídrica da atmosfera. Ocorreu uma boa aderência entres as duas curvas, embora observe-se, de modo análogo que ocorreu com tomateiro e com milho, valores mais elevados de fluxo de seiva em relação ao transpiração medida pela balança no período da manhã, na maioria dos dias. Deve-se ressaltar que as diferenças entre os dois fluxos podem ter ocorrido, em parte, pelo fato de a balança ter uma sensibilidade de $10 \mathrm{~g}$, ou seja, ela só indicava variações mínimas dessa ordem de grandeza.
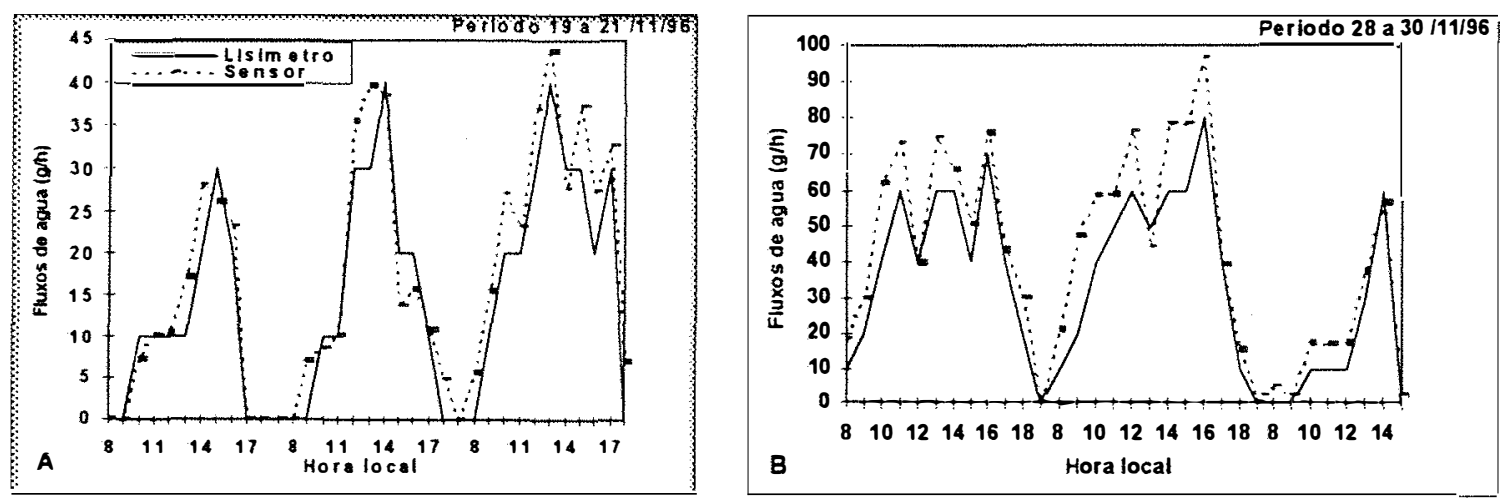

Figura 8 - Comparação horária entre as taxas transpiratórias determinadas por perda de peso (balança) e pelo método de calor (MBC) durante um período consecutivo de 3, em duas plantas, com área foliar de $0,3 \mathrm{M}^{2}(\mathrm{~A})$ e $0,28 \mathrm{M}^{2}(\mathrm{~B})$. 
Em torno do meio dia houve a tendência do fluxo de seiva ser maior que a transpiração, com exceção do segundo dia no segundo período, quando em um horário ele foi estimado como menor quando a demanda hídrica diminuiu. Além dos erros de medida, um efeito de capacitância hídrica poderia ter desencadeado uma defasagem entre as curvas, como observado por Steinberg et al. (1989), mas as indicações são de que se ocorreu capacitância hídrica, ela foi pequena.

As Figuras 9a e $9 \mathrm{~b}$ apresentam as correlações entre os valores e fluxos de seiva obtidos pelo método de balanço de calor e os de ranspiração por pesagem para intervalos de 1 hora; a partir dos períodos seqüenciais apresentados na Figura 7. Houve boa correlação entre os valores obtidos pelos dois métodos mas em geral os valores de fluxo de seiva mostraram superestimativa geral da ordem de 10 a $19 \%$ respectivamente.
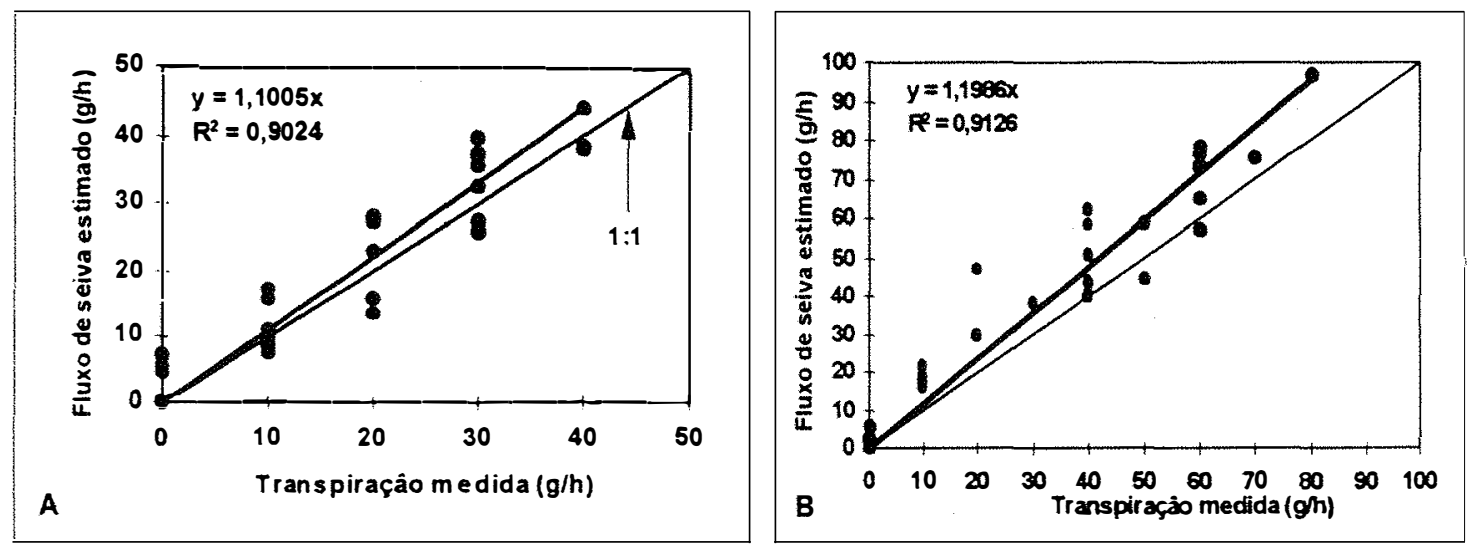

Figura 9 - Correlação entre os fluxos de seiva estimados pelo (MBC) e a transpiração medida gravimetricamente em períodos seqüenciais de 3 dias, na escala horária. 
A comparaçāo da perda de água acumulada em escala horária, como na escala diuma (8 a 18hs), durante um período de 30 dias é mostrada nas figuras (10a e 10b). Na escala horária a concordância entre os dois métodos foi menor com mais dispersão, em parte provavelmente devido à sensibilidade da balança, já na escala diária a dispersão é menor, mas a tendência à superestimativa dos fluxos é mantida principalmente nos períodos de maior demanda hídrica. Embora a correlação seja alta $\left(r^{2}=0,96\right)$ os fluxos de seiva apresentaram valores, em média $11 \%$ maiores que de transpiraçāo na escala horária e $13 \%$ na escala diuma. Além dos erros introduzidos pela sensibilidade da balança essa superestimativa dos fluxos de seiva pode ser atribuída a efeitos das condições ambientais sobre a dinâmica do sensor e a erros incluídos na equaçāo utilizada para estimativa dos fluxos pelo MBC, tais como a adoçāo de valores constantes para "Ksh" (coeficiente de transferência calorífica do fluxímetro) e para $\mathrm{Kc}$ (condutividade térmica do caule), já que ambas podem variar durante o dia, principalmente no caso do fluxímetro, como demonstrado por (Steinberg et al., 1989; Van Bavel \& Van Bavel, 1990; Senock \& Ham, 1993, 1995). 

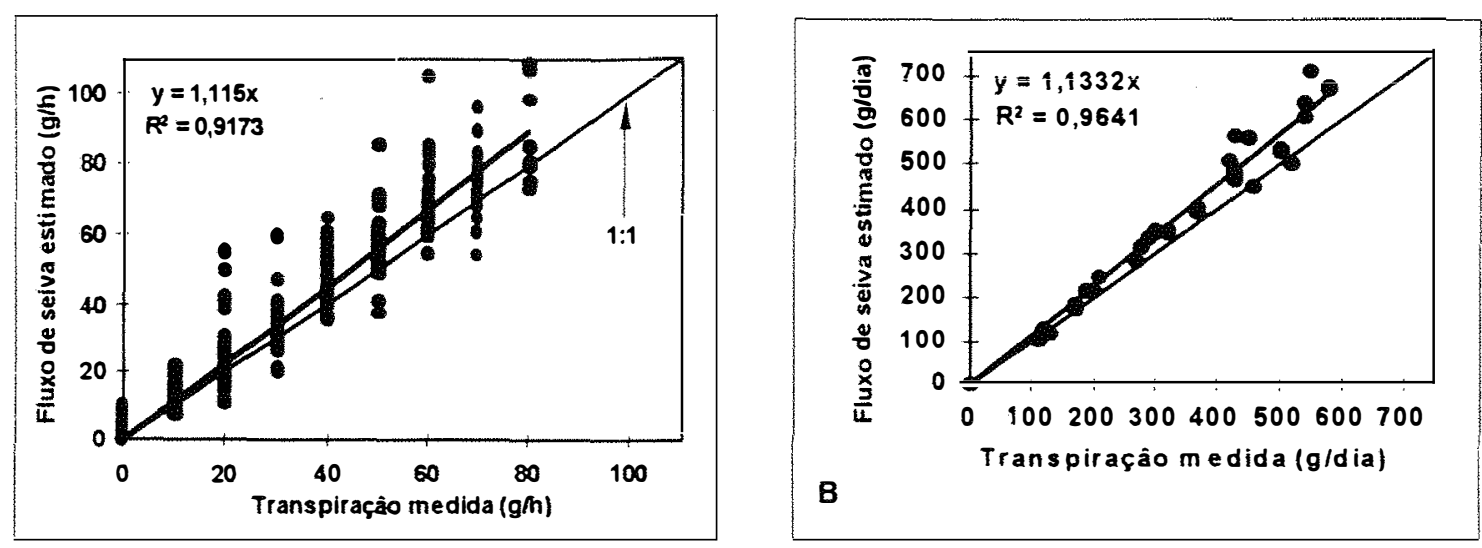

Figura 10 - Comparação da taxa transpiratória medida por balança e pelo método de balanço de calor $(\mathrm{MBC})$, durante um período de 30 dias. A: na escala horária; B: na escala diuma.

A variação da diferença de temperatura da seiva entre a sua entrada e a sua saída nos limites do segmento aquecido do caule (dTud), medida na superfície do caule em função do fluxo de seiva, é mostrada na (figura 11). A faixa de variação foi de $0,65^{\circ}$ até $2,47^{\circ} \mathrm{C}$ a qual está dentro dos valores encontrados por Valacogne e Nasr (1989) e Van Bavel \& Van Bavel (1990). Pode-se observar inicialmente um aumento e depois uma redução no valor de dTud com o incremento do fluxo, seguindo a relação típica das mediçōes de fluídos com traçadores térmicos como reportado por Van Bavel \& Van Bavel (1990), Ham \& Heilman (1990), Van Bavel \& McInnes (1991). 


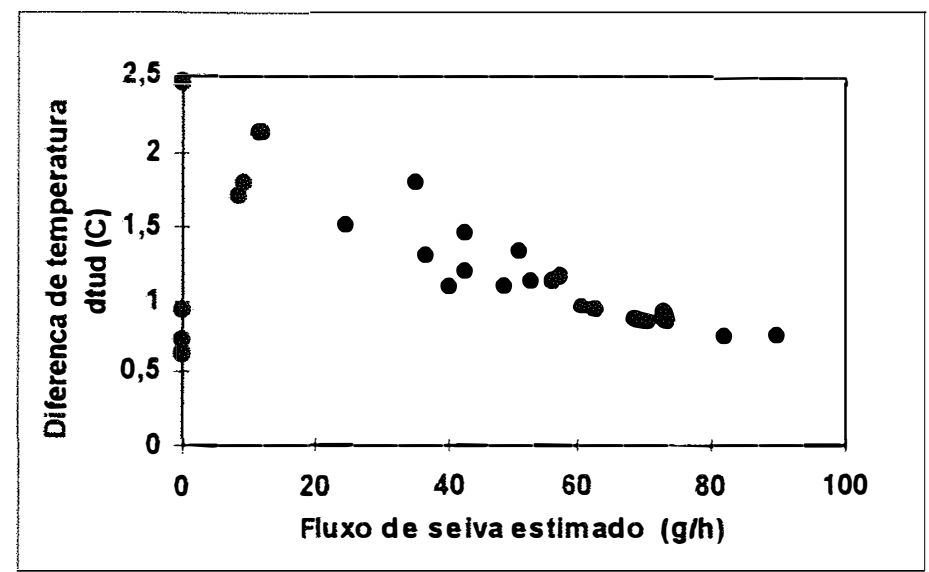

Figura 11 - Variação da diferença de temperatura entre as superfícies transversais do volume de caule com a variação do fluxo de seiva em limoeiro.

\subsection{Avaliaçao do desempenho do método e dos sensores de balanço de calor}

Uma avaliação correta do desempenho dos sensores exige uma análise mais profunda de diversos aspectos do método, incluindo: dinâmica da partição dos fluxos de calor; fontes potenciais de erro e a resposta dinâmica do sensor às variações do fluxo de seiva.

\subsubsection{Dinâmica dos fluxos dissipativos do calor fornecido}

As figuras $12 \mathrm{~A}$, B e C mostram exemplos da partição do fluxo de calor fomecido nos diferentes fluxos dissipativos, ao longo de alguns dias, para as espécies tomate, milho e limoeiro, respectivamente. 

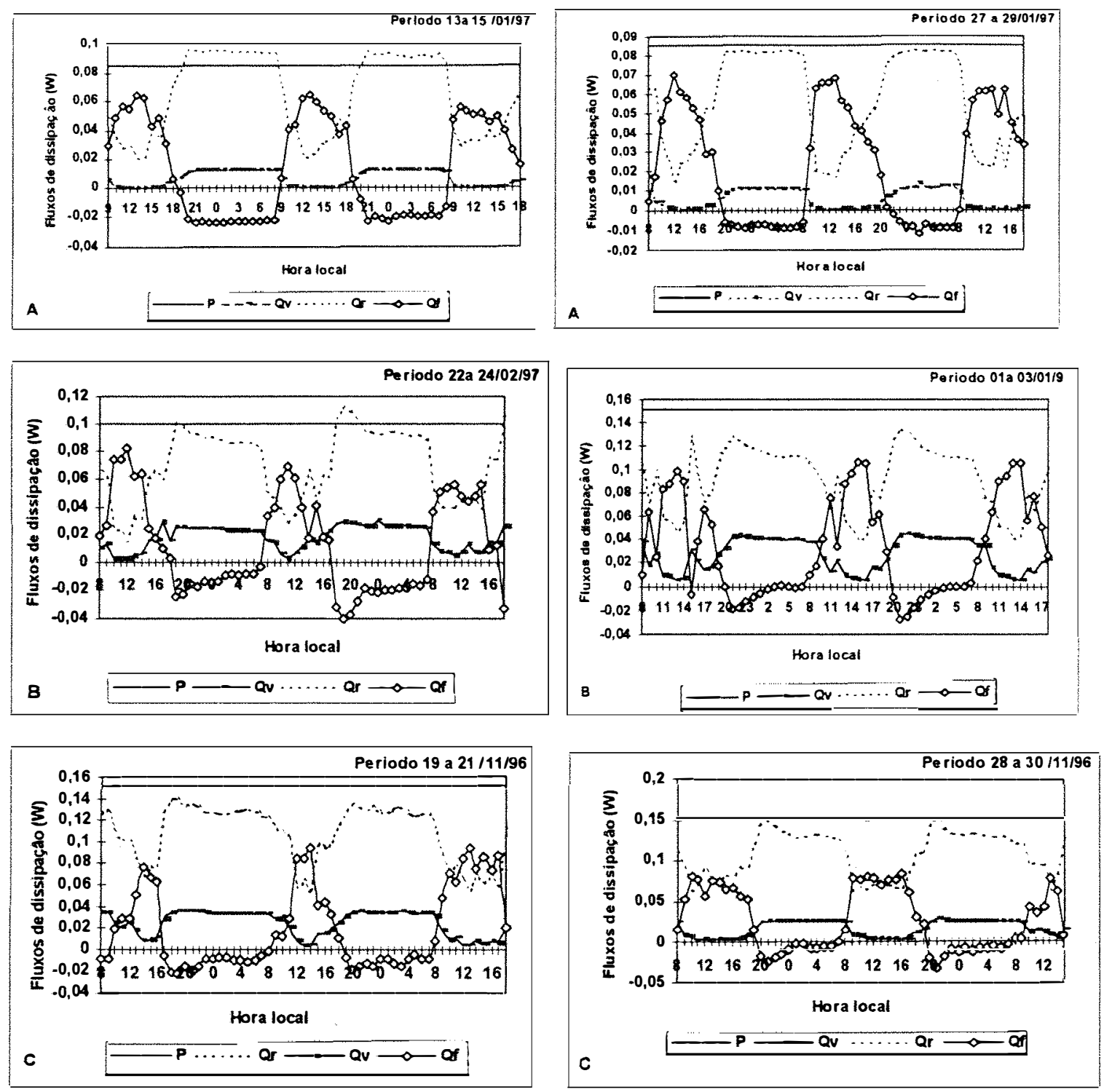

Figura 12 - Dinâmica dos fluxos de calor componentes do $\mathrm{MBC}$ em períodos consecutivos de 3 dias, de baixa e alta demanda hídrica. A: Tomate, B: Milho e C: Limoiro. 
Essas figuras permitem comparar a importância relativa de cada fluxo de calor, sob diferentes condições de fluxo de seiva. Durante o período de baixo fluxo de seiva, o componente $\mathrm{Q}_{\mathrm{r}}$ torna-se o fluxo dominante. Sob condições de alto fluxo hídrico, o termo $Q_{f}$ passa a ser o fluxo dominante, enquanto que $Q_{v}$ foi sempre o menor componente do balanço de calor em altos como em baixos fluxos de seiva. Esses padrōes relativos dos componentes do fluxo de calor são consistentes com os reportados por outros pesquisadores em diversas espécies de plantas (Steinberg, 1989; Ham \& Heilman, 1990; Devitt et al., 1993; Cohen et al., 1993; Ansley et al., 1994; Chandra et al., 1994; Zhang \& Kirkham, 1993; Weibel \& Boersma, 1995; Grime et al., 1995; Peressotti \& Ham, 1996).

\subsubsection{Fontes potenciais de erro na estimativa dos fluxos de seiva}

\subsubsection{Uso dos coeficientes Kc e Ksh}

Para estimativa dos fluxos de seiva o valor de Ksh (constante de transferência do fluxímetro radial) tem que ser determinado. Neste estudo os resultados apresentados foram obtidos usando o valor médio dos valores de Ksh estimados com os sinais emitidos pelo sensor durante o período noturno, assumindo nessas condiçōes fluxo de seiva igual a zero. Esses valores estiveram na faixa de 0,65 a $0,85 \mathrm{~W} \mathrm{mV}^{-1}$. 
Segundo Senock \& Ham (1993) incrementos de até 30\% podem ocorrer no transcurso do dia nos valores de "Ksh" devido à reduções na disponibilidade hídrica do solo; assim, flutuações no conteúdo hídrico da planta alteram as proporções volumétricas de água e celulose, com efeitos diretos nas propriedades térmicas do caule $(\mathrm{Kc})$ e na estimativa de (Ksh) pelas alterações de $Q_{v}$ e $Q_{r}$. Gerdes et al. (1994) estudando a sensibilidade do método as variações nos parâmetros de Kc e Ksh, pelo aumento e pela diminuição dos valores dessas constantes em $10 \%$ reportam erros de -1,8 até +9,2 e de 8,2 a $+37,5 \%$ na estimativa dos fluxos de seiva respectivamente. Alguns, autores consideram mais apropriado o uso de valores Ksh estimados em partes cortadas de caule para a estimativa de fluxos maiores que $50 \mathrm{~g} \mathrm{~h}^{-1} \mathrm{e}$ valores de Ksh estimados nas primeiras horas da manhã para fluxos menores (Ham \& Heilman, 1993; Senock \& Ham, 1995). Durante baixos fluxos, $Q_{r}$ é o componente dominante dos fluxos de calor (Fig. 12 A, B, C), assim pequenos erros nas medidas de Ksh, tem potencialmente grandes erros nas estimativas dos fluxos de seiva. Van Bavel \& Van Bavel (1990) reportam incrementos de até $60 \%$ nos valores de Ksh quando a potência é incrementada em apenas 0,0001 watt em sensores comerciais; assim, assumir um só valor de Ksh como feito neste trabalho, pode conduzir a erros substanciais na estimativa diária dos fluxos de seiva, principalmente quando esse fluxo é baixo. 


\subsubsection{Medidas de temperatura para estimativa dos fluxos condutivos e convectivos} axiais

Outra variável importante na operação do sensor é o valor de dTud, que reflete o aquecimento da seiva durante sua passagem pelo segmento de caule aquecido. Os componentes dominantes dos fluxos de dissipação de calor são $Q_{f}$ e $Q_{r}$ para altos e baixos fluxos, respectivamente (Figura 12 A,B,C) e mudanças nestes fluxos têm implicações potenciais de erro na estimativa dos fluxos de seiva (Baker \& Nieber, 1989; Groot \& King, 1992; Senock \& Ham, 1993; Weibel \& Boersma, 1995), pois $Q_{f}$ é calculado usando-se dTud.

Quando a disponibilidade hídrica do solo é alta e a taxa transpiratória é baixa, a diferença de temperatura (dTud) e inicialmente alta e decresce rapidamente quando o fluxo é máximo (Figura 7A, 7B; Figura 11). Na equação para a estimativa do fluxo de seiva (equação 10), os componentes de balanço $\left(Q_{v}, Q_{r}\right.$ e dTud) são obtidos através de saídas diretas do sensor e $\mathrm{Q}_{\mathrm{f}}$ é calculado como termo residual. Durante altos fluxos de seiva, quando a importância de $\mathrm{Q}$ diminue, $\mathrm{Q}_{\mathrm{f}}$ passa a ser o componente mais importante no balanço. Nesses momentos, segundo Baker \& Nieber (1989), Ham \& Heilman, 1990, Ishida et al. (1991); Cohen et al. (1993), Senock \& Ham (1993), erros na estimativa são mais prováveis, pela falta de equilíbrio térmico entre a superfície do caule e a corrente transpiratória, pelos fortes gradientes na periferia do mesmo, conduzindo à superestimativa 
dos fluxos axiais $\left(Q_{f}\right.$ e $\left.Q_{v}\right)$ e subestimativa dos fluxos radiais e conseqüentemente, erros no fluxo de seiva computado, principalmente nos momentos em que ele é alto.

A derivada parcial da equação (14) em relação a dTud (Senock \& Ham, 1993),

$$
\delta F / \delta d T u d=-Q_{F}^{\prime}\left[C_{p} \cdot(d T u d)^{2}\right]
$$

mostra que variações no fluxo $(F)$ são diretamente proporcionais a $Q_{f}$ e inversamente proporcionais a (dTud) ${ }^{2}$, assim sendo $(F)$ é susceptivel a grandes erros quando $Q_{\mathrm{f}}$ é grande e os valores de (dTud) são menores de $1^{\circ} \mathrm{C}$.

Senock \& Ham (1993) mostraram que em condições de fluxos maiores de $50 \mathrm{~g} \mathrm{~h}^{-1}$ erros de $0.1^{\circ} \mathrm{C}$ na estimativa de (dTud) conduzem a erros de $15 \%$ na estimativa dos fluxos de seiva. Nos resultados apresentados a diferença mínima de temperatura registrada nos limites superior e inferior do segmento de caule aquecido (dTud) foi de $0,62^{\circ} \mathrm{C}$ (Figuras 6A, 6B e Figura 10). Então, os valores de dTud encontrados são indicativos de que trabalhou-se com uma potência adequada, isto é, nem muito elevada de modo a causar danos no caule, mas nem muito baixa de modo a tornar a estimativa de $\mathrm{F}$ muito sensível ao valor de dTud, isto é, está de acordo com o descrito por Levitt et al. (1991), Cohen et al. (1993) e Gerdes et al. (1994), que trabalharam com potência aplicada 
no sentido de evitar valores de dTud inferiores a $0,5^{\circ} \mathrm{C}$. Isso deve ter minimizado os erros devido à sensibilidade da estimativa de $\mathrm{F}$ aos valores de dTud, mas evidentemente não eliminou os erros devidos à representatividade da medida de temperatura nas secções transversais do segmento de caule aquecido. Para milho e limoeiro, tentou-se melhorar essa representatividade, fazendo-se 4 repetições de medidas na superfície do caule; evidentemente, medidas em profundidade seriam mais adequadas, conforme demonstrou Stockle et al. (1991), mas esse procedimento, em contrapartida, tem o inconveniente de tomar o método invasivo.

\subsubsection{Estimativa da variação de armazenamento de calor no caule}

A taxa de variação de calor armazenado no caule é geralmente ignorado, principalmente em plantas herbáceas, pela pequena porção de segmento aquecido e o rápido equilíbrio dinâmico atingido (Ham \& Heilman, 1990); dessa forma, a magnitude do calor armazenado é muito pequena em relação aos outros componentes do balanço de calor (Van Bavel \& McInnes, 1991); em baixos fluxos, entretanto, o termo de calor armazenado pode ser incluído nos cálculos (Groot \& King, 1992).

Poucos trabalhos têm avaliado a participação de $\mathrm{Q}_{\mathrm{s}}$ no balanço de calor em plantas herbáceas e os resultados concluem ser possível negligenciar esse componente porque os ajustes nos fluxos de seiva por sua in rodução são mínimos (aproximadamente 1

$\left.\mathrm{g} \operatorname{dia}^{-1}\right)$, atribuindo os erros potenciais na estimativa dos fluxos de seiva a medidas dos 
fluxos dominantes do balanço de calor $\mathrm{Q}_{\mathrm{f}}$ e $\mathrm{Q}_{\mathrm{r}}$ (Van Bavel \& McInnes, 1991; Senock \& Ham, 1993, 1995; Grime et al., 1995).

Steinberg et al. (1989) reportam uma boa concordância entre o fluxo de seiva e a transpiração em plantas de Ficus com diâmetro de $45 \mathrm{~mm}$; entretanto, Valancogne \& Nasr (1993), Weibel \& de Vós (1994), Weibel \& Boersma (1994) e Grime et al. (1995), sugerem que esse componente não deve ser ignorado para plantas com diâmetros maiores de $30 \mathrm{~mm}$, sugerindo também que sob curtos períodos de tempo, erros sistemáticos podem ser corrigidos mediante a estimativa de $\mathrm{Q}_{\mathbf{s}}$.

Nos resultados de comparação entre o fluxo de seiva estimado pelo MBC e de transpiração por pesagem mostrados anteriormente, o termo $\mathrm{Q}_{\mathrm{s}}$ foi desprezado. Mas, estudos posteriores foram realizados para avaliar a participação desse termo no balanço de calor no caule de mudas de limoeiro. Uma junção de termopar foi inserida no interior do caule (aproximadamente $4 \mathrm{~mm}$ ), na parte central do segmento aquecido e monitorada a variação de temperatura de caule, como recomendada por Valancogne (s/d). Os resultados são apresentados nas Figuras (13, 14 e 15).

A Figura 13 mostra a variação de temperatura do caule e a taxa horária de variação $(\Delta \mathrm{T} / \mathrm{dt})$ num período consecutivo de 3 dias. 


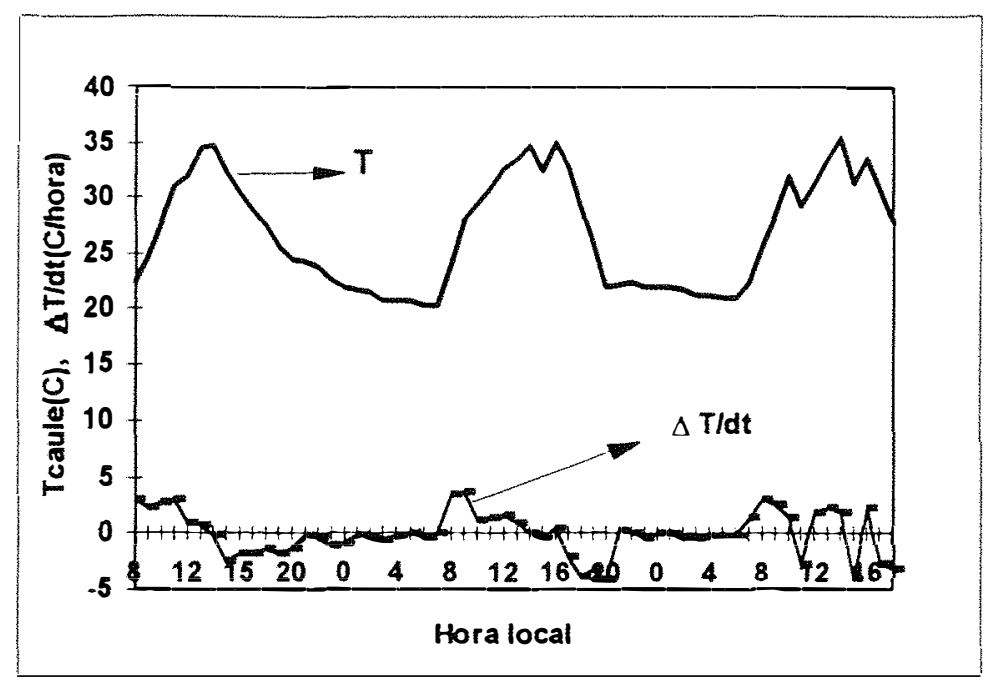

Figura 13 - Variação da temperatura do caule e a taxa de variação $(\Delta \mathrm{T} / \mathrm{dt})$ para um período consecutivo de 3 dias.

As plantas são seres poicilotermos e a sua temperatura tende a acompanhar a temperatura ambiente, sendo as variaçōes de $\mathrm{T}$ na figura 13, uma conseqüência desse fato. No caso da medida feita no segmento aquecido de caule, ocorre uma situação particular pois calor adicional ao do ambiente está sendo fornecido. No segmento, a participação de calor fornecido acaba afetado por essa situação e pelo próprio fluxo convectivo pela seiva. Isso condiciona variações da taxa de variação da temperatura, relacionado ao armazenamento calorífico no segmento. Nas primeiras horas da manhã, a taxa de variação da temperatura do caule é relativamente alta $\left(2\right.$ a $3^{\circ} \mathrm{C} /$ hora $)$, mas depois, mesmo com o aumento da temperatura ambiente, essa taxa diminue principalmente em função do aumento do fluxo convectivo, podendo-se atingir valores próximos e até abaixo 
de zero nos picos máximos de fluxos de seiva e, ainda, nos momentos que ocorrem rápidas flutuações térmicas no ambiente, como reportado por Shackel et al. (1992) e Grime et al. (1995).

A importância relativa do fluxo de calor armazenado no caule no balanço de calor ao longo do tempo, em três dias de medida em mudas de limoeiro, pode ser visualizada na figura 14.

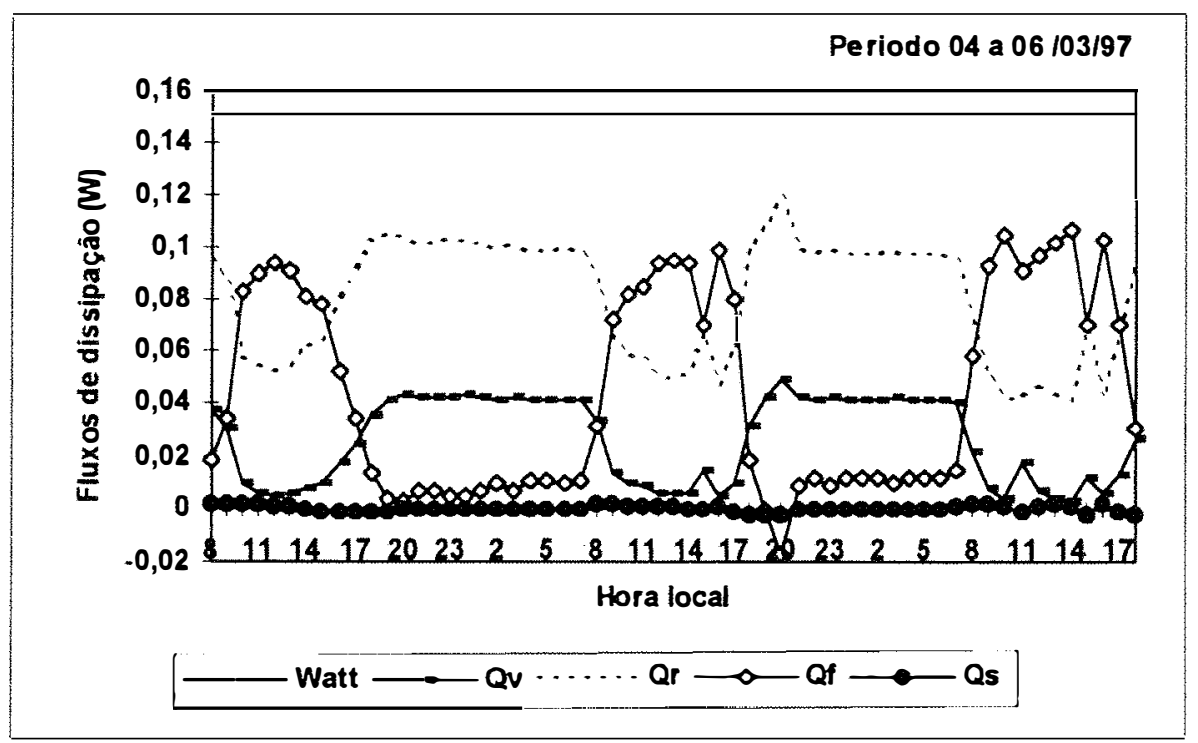

Figura 14 - Componentes de dissipação de calor do Método de Balanço de Calor incluindo a variação de temperatura do caule $\left(\mathrm{Q}_{\sharp}\right)$.

Sua contribuição no balanço de calor foi muito pequena, refletindo-se em modificações desprezíveis no valor estimado de F. Quando o fluxo de seiva é baixo, o valor relativo de $\mathrm{Q}_{s}$ torna-se maior no balanço; por exemplo, no início da manhã, a 
introdução de $\mathrm{Q}_{s}$ nos cálculos pode causar uma variação de cerca de até $10 \%$ no valor de F, nos momentos de altos fluxos, seu efeito na estimativa dos fluxos de seiva é desprezível, o que pode ser observado nas Figuras 15 e 16, o que está de acordo com os resultados reportados por Valancogne \& Nasr, 1993, Grime et al. (1995), Weibel \& Boersma (1995) em plantas lenhosas com diâmetros menores de $30 \mathrm{~mm}$.

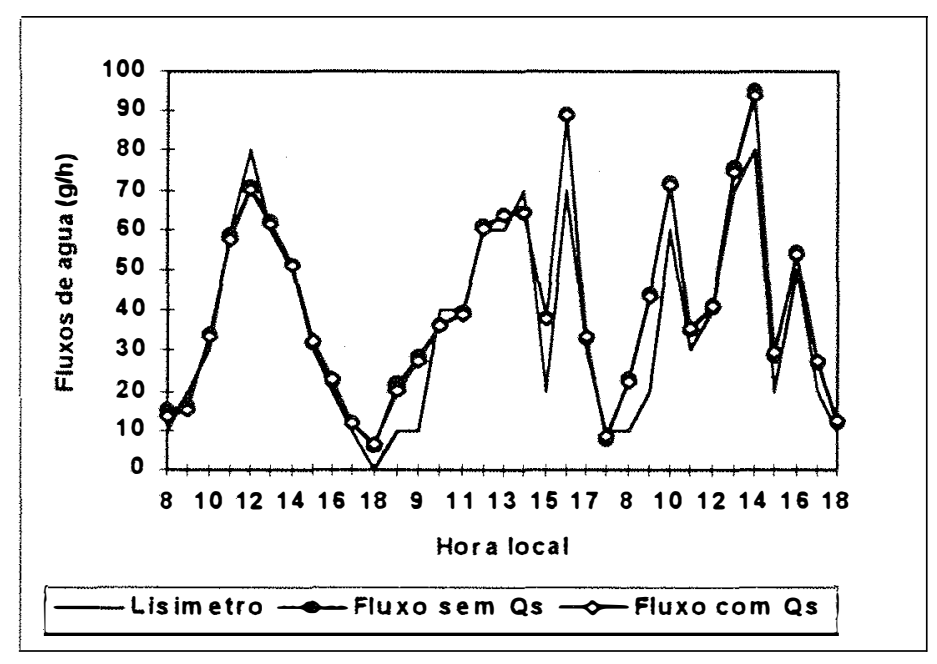

Figura 15 - Comparação da transpiração medida gravimetricamente e de fluxo de seiva estimado pelo Método de Balanço de Calor em muda de limoeiro, incluindo e negligenciando o valor de $\mathrm{Q}_{s}$. 


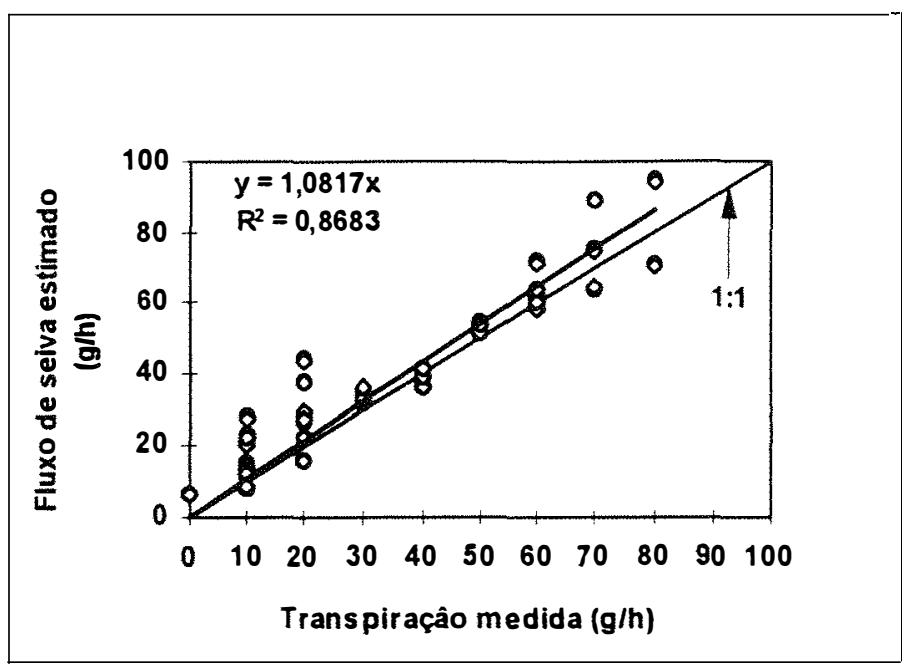

Figura 16 - Correlação dos fluxos acumulados durante um período seqüencial de 3 dias, incluindo (símbolos abertos) e negligenciando (símbolos fechados) o valor de Q.

A indução de gradientes de temperatura pelas condições ambientais no interior do sensor e a conseqüente alteração do equilibrio térmico é amplamente documentada (Levitt et al., 1991; Shacket et al., 1992; Gerdes et al., 1994; Gutierrez et al., 1994; Weibel \& Boersma, 1995; Grime et al., 1995; Senock \& Ham, 1995).

Nas figuras que mostram a dinâmica dos fluxos de dissipação de calor (Figuras 11A,B,C) pode ser observada a ocorrência de mudanças repentinas no equilíbrio dinâmico dos componentes do balanço de calor, alterando principalmente o equilibrio entre $Q_{r}$ e $Q_{F}$, e a conseqüente sub ou superestimativa dos fluxos de seiva. $Q_{v}$ praticamente permanece inalterado. Essas rápidas mudanças provavelmente sejam uma resposta às flutuações térmicas do meio ambiente, como demonstrado por Senock \& Ham (1995), 
mediante sistema arificial de fluxo constante, aquecendo e resfriando a lamina refletiva do isolante térmico, reportando que o aquecimento de $25^{\circ} \mathrm{C}$ até $70^{\circ} \mathrm{C}$ causava uma alteração no equilíbrio de $\mathrm{Q}_{\mathrm{r}}$ de $+0,047 \mathrm{~W}$ para $-0,04 \mathrm{~W}$, superestimando os fluxos em $200 \%$; pelo resfriamento da lamina refletiva de $25^{\circ} \mathrm{C}$ para $13^{\circ} \mathrm{C}$, os resultados se inverteram. Isso demonstra que o neopreno, isolante comumente utilizado na elaboração dos sensores, pode não estabelecer um isolante térmico completo do caule quando ocorrem variações rápidas da temperatura do ar.

Segundo Senock \& Ham (1995), pode-se calcular a transferência de calor através do sensor e se estimar uma espessura do isolante que permita minimizar seus efeitos sobre a medida, utilizando a equação citada por Incropera \& De Witt (1990).

$$
q=\frac{\Delta T}{\ln \left(r_{1} / r_{2}\right) / 2 \pi \cdot L \cdot K_{c o}}
$$

onde q é o fluxo de calor transferido, $\Delta \mathrm{T}$ é a diferença de temperatura entre o caule e a superfície do sensor, $r_{1}$ é a distância da superfície do caule ao isolante (m), $r_{2}$ é o raio do caule isolado (m); L é a altura da jaqueta térmica e $\mathrm{K}_{\infty}$ a condutividade térmica do material isolante $\left(0,039 \mathrm{~W} \mathrm{~m}^{-1} \cdot \mathrm{c}^{-1}\right)$. Como para um isolante em particular, $\mathrm{K}_{\infty}$ é constante, então "q" vai depender diretamente da espessura do isolante (r), incrementando (r), "q" decresce, ocorrendo um menor impacto das variações externas da temperatura no balanço térmico do sensor. 
Aplicando o raciocínio de Senock \& Ham (1995), os valores específicos para o presente trabalho, verificou-se que nas plantas de tomate, para manter uma diferença de temperatura de $2^{\circ} \mathrm{C}$ e reduzir o impacto das variações térmicas ambientais a $\pm 0,003 \mathrm{~W}$, a espessura de neopreno necessária seria de $34 \mathrm{~mm}$, bem maior do que a utilizada. $\mathrm{O}$ valor de $\mathrm{K}_{\infty}$ utilizada nos cálculos foi de $0,039 \mathrm{Wm}^{-1} \cdot{ }^{\circ} \mathrm{C}^{-1}$, citado por aqueles autores, pois não se tinha esse valor específico para o neopreno utilizado neste trabalho, o que poderia levar a valores de espessura adequada diferentes de $34 \mathrm{~mm}$, mas de qualquer maneira, há indicação de que as espessuras utilizadas nas três espécies podem não ter sido as mais adequadas, levando a problemas de isolamento e de efeito sobre as medidas quando ocorreram variações térmicas no ambiente.

\subsubsection{Resposta dinâmica do sistema}

Os resultados do estudo da resposta dinâmica do sistema de medida, nas 3 espécies utilizadas são amostradas nas Figuras 17A,B,C. 

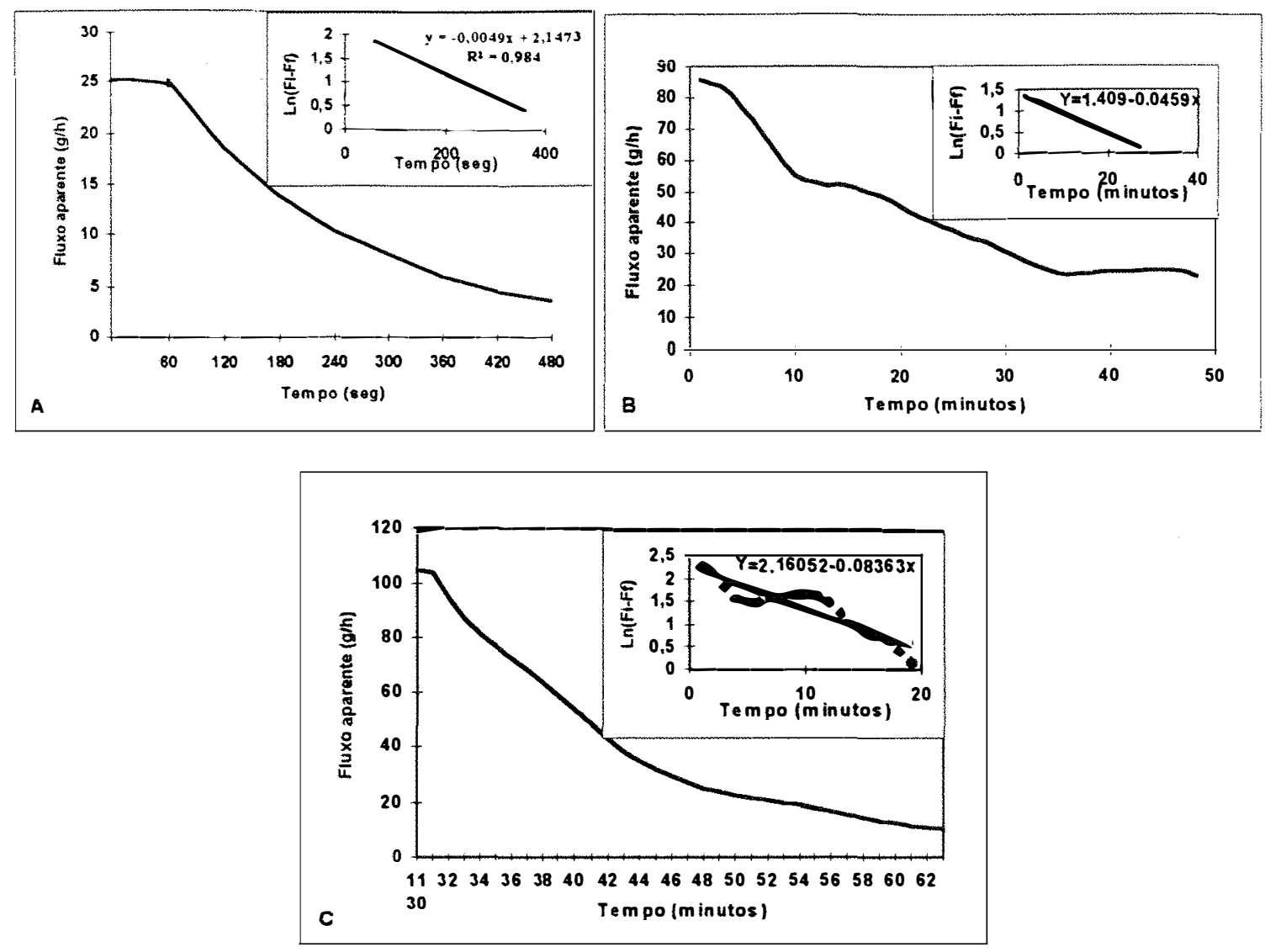

Figura 17 - Variações no fluxo aparente da seiva após excisão da parte aérea, registrado a cada minuto. (Figura inserida: Sistema da constante de tempo derivada da diferença entre fluxo inicial $\left(\mathrm{F}_{1}\right)$ e Fluxo Final $\left(\mathrm{F}_{\mathrm{F}}\right)$ até que o sensor registrasse uma redução de $63 \%$ do fluxo inicial. A: Tomate; B: Milho; C: Limoeiro.

A taxa do fluxo de seiva no momento do corte do caule era de 26,82 $\mathrm{g} \mathrm{h}^{-1}, 87,4 \mathrm{~g} \mathrm{~h}^{-1}$ e $104,5 \mathrm{~g} \mathrm{~h}^{-1}$, para tomate, milho e limoeiro, respectivamente, e as constantes de tempo, estimadas para esses testes, foram de 3,4, 21 e 11,9 minutos respectivamente. Resultados semelhantes foram obtidos em outros testes com taxas de 
fluxos diferentes. Os valores estimados são da ordem de grandeza obtida em diversos trabalhos, tanto em herbáceas como em lenhosas (Baker \& Van Bavel, 1987; Steinberg et al., 1989; Senock \& Ham, 1993, 1995; Peressotti \& Ham, 1996). Ressalta-se que essa constante de tempo é referente a situações de fluxo relativamente alto e caules de pequeno diâmetro. A baixa constante de tempo é uma indicação de que a resposta dinâmica dos sensores às variações do fluxo de seiva, nas condições experimentais, é suficiente para estudos da dinâmica do transporte hídrico em intervalos de tempo da ordem de 20 minutos em tomateiro, plantas de milho e mudas de limoeiro, para fins fisiológicos ou agronômicos. 


\section{CONCLUSÕES}

- O método do balanço de calor permitiu estimativas de fluxo de seiva em boa concordância com a transpiração medida, em escala de 1 hora e na escala de 10 horas, nas três espécies. Houve tendência dos valores de fluxo de seiva estimados serem em média 5 a $10 \%$ maiores que os de transpiração, tanto nos valores acumulados na escala horária, como na diurna, para tomate, 7 a $17 \%$ em milho e 10 a $20 \%$ em mudas de limoeiro.

- Em geral, houve tendência dos valores de fluxo de seiva e de transpiração apresentarem maiores discrepâncias em plantas de milho, do que nos tomateiros e nas mudas de limoeiro.

- No período da manhã e nas horas de maior demanda hídrica da atmosfera, os valores de fluxo de seiva foram superiores aos de transpiração, o que pode ser uma indicação da existência de erro principalmente na parte da manhã, no método de balanço de calor. 
- Nos períodos de menor demanda hídrica, o fluxo de calor no sentido radial predominou sobre os demais componentes do balanço de calor, enquanto que nos de maior demanda, o fluxo de calor predominante foi o transportado convectivamente pela seiva, nas três espécies.

- A introdução do termo de variação de armazenamento de calor no balanço não contribuiu para melhorar a estimativa do fluxo de seiva em mudas de limoeiro.

- Ocorreram indicações, principalmente nos momentos de baixo fluxo hídrico, de que a adoção de um só valor para o coeficiente de transferência calorífica (Ksh) do fluxímetro, que mede o fluxo radial de calor, é uma fonte de erros nas estimativas.

- A análise física matemática indicou que o isolamento térmico dos sensores deveria ser mais espesso, para se ter eficiência de isolamento maior nos momentos de altas flutuações térmicas.

- As constantes de tempo de resposta a variação brusca do fluxo de seiva indicam que os sensores tiveram, resposta dinâmica suficiente para se trabalhar com variações de fluxo em períodos de 20 minutos nas três espécies. 


\section{REFERÊNCIAS BIBLIOGRÁFICAS}

ANSLEY, J.R.; DUGAS, W.A.; HEUER, M.L. et al. Stem flow and porometer measurements of ranspiration from honey mesquite (Prosopis glandulosa). Journal of Experimental Botany, v.45, n.275, p.847-856, 1994.

BAKER, J.M.; BAVEL, C.H.M. van. Measurement of mass flow of water in the stems of herbaceous plants. Plant, Cell and Environment, v.10, p.777-782, 1987.

BAKER, J.M.; NIEBER, J.L. An analysis of the steady-state heat balance method for measuring sap flow in plants. Agricultural and Forest Meteorology, v.48, p.93109, 1989.

BAVEL, C.H.M. van; McINNES. Significance of heat storage in the use of stem gauges. In: ANNUAL MEETING OF AMERICAN SOCIETY OF AGRONOMY, 83., Denver, 1991. Symposium of sap flow measurement. Denver: ASA, 1991. p.29-30. 
CERMAK, J.; DEML, M.; PENKA, M. A new method of sap flow rate determination in trees. Biologia Plantarum, v.15, n.3, p.177-178, 1973.

CERMAK, J.; KUCERA, J.; PENKA, M. Improvement of the method of sap flow rate determination in full-grown trees based on heat balance with direct electric heating of xylem. Biologia Plantarum, v.18, n.2, p.105-110, 1976.

CHANDRA, S.; LINDSEY, R.A.; BASSUK, N.L. A gauge to measure the mass flow rate of wate of water in trees. Plant, Cell and Environment, v.17, p.867-874, 1994.

CLOSS, R.L. The heat pulse method for measuring rate of sap flow in a plant stem. New Zealand Journal Science, v. 1, p.281-288, 1958.

COHEN, Y.; FUCHS, M.; GREEN, G.C. Improvement of the heat pulse method for determining sap flow in trees. Plant, Cell and Environment, v.4, p.391-397, 1981.

COHEN, Y.; FUCHS, M.; FALKENFLUG, V. et al. Calibrated heat pulse method for determining water uptake in cotton. Agronomy Journal, v.80, p.389-402, 1988. 
COHEN, Y.; TAKEUCHI, J.; NOZAKA, J. et al. Accuracy of sap flow measurement using heat balance and heat pulse methods. Agronomy Journal, v.85, p.1080-1086, 1993.

DAUM, C.R. A method for determining water transport in trees. Ecology, v.48, p.425$431,1967$.

DEVITT, D.A.; BERKOWITZ, M.; SCHULTE, P.I.J. et al. Estimating transpiration for three woody ornamental tree species using stem flow gauges and lysimetry. HortScience, v.28, n.4, p.320-322, 1993.

DOLEY, D.; GRIEVE, B.J. Measurement of sap flow in a eucalypt by thermo-eletric methods. Australian Forestry Research, v.2, n.1, p.3-27, 1966.

ESSAU, K. Anatomy of seed plants. New York: John Willey, 1960. p.238-257: The stem: secondary state of growth and structural types.

FICHTNER, K.; SCHULZE, E.D. Xylem water flow in tropical vines as measured by a steady state heating method. Oecologia, v.82, p.683-690, 1993. 
GAVLOSKI, J.E.; WHITFIELD, G.H.; ELLIS, C.R. Effect of larvae of western com root worm (Coleoptera: Crysomelidae) and of mechanical root pruning on sap flow and growth of com. Journal of Economic Entomology, v.85, n.4, p.1434-1441, 1992.

GERDES, G.; ALLISON, B.E.; PEREIRA, S.L. Over estimation of soybean crop transpiration by sap flow measurement under field conditions in central Portugal. Irrigation Science, v. 14, p.135-139, 1994.

GRANIER, A. Une nouvelle methode pour la mesure du flux de seve brute dans le tronc des arbres. Annales des Sciences Forestiers, v.42, p. 193-200, 1985.

GRIME, V.L.; MORISON, J.L.; SIMMONDS, L.P. Sap flow measurements from stem heat balance: a comparison of constant with variable power methods. Agricultural and Forest Meteorology, v.74, p.27-40, 1995.

GROOT, A.; KING, M.K. Measurement of sap flow by the heat balance method: numerical analysis and application to coniferous seedlings. Agricultural and Forest Meteorology, v.59, p.289-308, 1992. 
GUTIERREZ, M.V.; HARRINGTON, R.A.; MEINZER, F.C. et al. The effect of environmentally induced stem temperature gradients on transpiration estimates from the heat balance in two tropical woody species. Tree Physiology, v.14, p. 179-190, 1994.

HAM, M.J.; HEILMAN, J.L. Dynamics of a heat balance stem flow gauge during high flow. Agronomy Journal, v.82, p.147-152, 1990.

HAM, M.J.; HEILMAN, J.L.; LASCANO, R.J. Determination of soil water evaporation and transpiration from energy balance and stem flow measurements. Agricultural and Forest Meteorology, v.52, p.287-301, 1990.

HEILMAN, J.L.; HAM, M.J. Measurement of mass flow rate of sap in Ligustrum japonicum. HortScience, v.25, n.4, p.465-467, 1990.

HEILMAN, J.L.; BRITTIN, C.L.; ZAJICE, J.M. Water use by shrubs as affected by energy exchange with building walls. Agriculture and Forest Meteorology, v.48, n.4, p.345-357, 1989.

HEINE, W.R.; DENIS, J.F. Comparison of heat pulse and radioisotope tracer methods for determining sap-flow velocity in stem segments of poplar. Journal of Experimental Botany, v.24, n.81, p.649-554, 1973. 
HUBER, B. Beobachtung and messung pflanzlicher softsttröme. Berichte. Deutsche Botanische Gesellschaft, v.50, p.84-109, 1932.

HUBER, B.; SCHMIDT, F. Eine kompensations method zur thermoelektrischen messung lang samer sofstsome. Gesellschaft Beritchte, v.55, p.514-519, 1937.

INCROPERA, P.F.; DE WITT, D. Fundamentals of heat and mass transfer. 3.ed. New York: John Wiley, 1990. 911 p.

ISHIDA, T.; CAMPBELL, S.G.; CALISENDORFF, C. Improved heat balance method for determining sap flow rate. Agricultural and Forest Meteorology, v.56, p.35-48, 1991.

KITANO, M.; EUGUCHI, H. Quantitative analysis of anspiration steam, dynamics in an intact cucumber stem by a heat flux control method. Plant Physiology, v.89, p.643-677, 1989.

KUCERA, J.; CERMAK, J.; PENKA, M. Improved thermal method of continual recording the transpiration flow rate dynamics. Biologia Plantarum, v.19, p.413420, 1977. 
KRAMER, P.J. Water relations of plants. New York: Academic Press, 1983. p.187214: Water movement in the soil-plant-atmosphere continuum.

LEVITT, D.G.; SIMPSON, J.R.; TIPTON, J.L. Effects of thermal noise on stem flow gauge performance. In: ANNUAL MEETING OF AMERICAN SOCIETY OF AGRONOMY, 83., Denver, 1991. Symposium of sap flow measurement. Denver: ASA, 1991. p.15-16.

LUNDEGARD, H. The transport of water in wood. Arkansas Botany, Ser.2, v.2, n.2, p.89-119, 1954.

MARSHALL, D.C. Measurement of sap-flow in conifers by heat transfer. Plant Physiology, v.33, p.385-396, 1958.

PERESSOTTI, A.; HAM, J.M. A dual heater gauge for measuring sap flow with and improved heat-balance method. Agronomy Journal, v.88, p. 149-155, 1996.

PICARD, W.F.; PUCCIA, C.J. A theory of the steady-state heat step method of measuring water flux in woody plant stems. Mathematical Biosciences, v.14, p.1-15, 1972. 
PURITCH, G.S. Water permeability of the wood of grand fir (Abies grandis (Doug.) Lindl.) in relation to infestation by the balsam woolly aphids, Adelges piceae (Ratz.). Journal of Experimental Botany, v.22, n.73, p.936-945, 1971.

PURITCH, G.S.; PETTY, G.A. Effect of balsam woolly aphid, Adelges piceae (Ratz.), infestation on the xylem of (Abies grandis (Doug.) Lindl.). Journal of Experimental Botany, v.22, n.73, p.946-952, 1971.

SAKURATANI, T. Apparent thermal conductivity of rice stems in relation to transpiration stream. Journal of Agricultural and Meteorology, v.34, n. $\dot{4}$, p. $177-$ 189, 1979.

SAKURATANI, T. A heat balance method for measuring water flux in the stem of intact plants. Journal of Agricultural and Meteorology, v.73, n.1, p.9-17, 1981.

SAKURATANI, $\mathrm{T}$. Improvement of the probe for measuring water flow rate in intact plants with the stem heat balance method. Journal of Agricultural and Meteorology, v.40, p.273-277, 1984 . 
SAKURATANI, T. Studies on evaporation from crops, separated, stimation of transpiration and evaporation from a soybean field without water shortage. Journal of Agricultural and Meteorology, v.42, p.309-317, 1987.

SCHACKEL, A.K.; SCOTT-JOHNSON, R.; MEDAWAR, C.K. Substancial errors in estimates of sap flow using the heat balance technique on woody stem under field conditions. Journal of the American Society for Horticultural Science, v.117, n.2, p.351-356, 1992.

SCHULZE, E-D.; CERMAK, J.; MATYSSEK, R. et al. Canopy transpiration and water fluxes in the xylem of the trunk of Larix and Picea trees, a comparison of xylem flow, porometer and cuvette measurements. Oecologia, v.66, p.475-483, 1985.

SENOCK, R.S.; HAM, J.M. Heat balance sap flow gauge for small diameters stem. Plant, Cell and Environment, v.16, p.593-601, 1993.

SENOCK, R.S.; HAM, J.M. Measurement of water use by prairie grasses with heat balance sap flow gauges. Journal of Range Management, v.48, p.150-158, 1995.

SERWAY, A.R. Physics for Scientist \& Engineers. Phyladelfia: Saunders College Publishings, 1986. 1169p. (Saunders Golden Sunburst Series). 
SHERIFF, W.D. A new apparatus for the measurements of sap flux in small shoots with the magnetohydrodynamic tecnique. Journal of Experimental Botany, v.23, n.77, p.1086-1095, 1972.

SLAVIK, B. Methods of studying plant water relations. Prague: Academia Publishing House of the Czechoslavak Academy Sciences, New York: Springer-Verlag, 1974. 449p.

STEINBERG, S.; BAVEL, C.H.M. van; McFARLAND, M. A gauge to measure mass flow rate of sap in stems and trunk of woody plants. Journal of American Horticultural Science, v.114, n.3, p.466-472, 1989.

STEINBERG, S.; BAVEL, C.H.M. van; McFARLAND, M.J. Short-term effect of uniconazole on the water relations and growth of Ligustrum. Journal of the American Society HortScience, v. 116, p.460-464, 1991.

STEINBERG, S.; ZAJICEK, J.M.; McFARLAND, M.J. Water relations of nibiscus following prunning on chemical growth regulation. Journal of the American Society HortScience, v.116, p.465-470, 1991. 
STOCKLE, C.O.; KJELGAARD, J.F. et al. Measuring sap with the heat balance approach using constant and variable heat imput. In: ANNUAL MEETING OF AMERICAN SOCIETY OF AGRONOMY, 83., Denver, 1991. Symposium of sap flow measurement. Denver: ASA, 1991. p.25-26.

SWANSON, R.H. Water transpired by trees is indicated by heat pulse velocity. Agricultural Meteorology, v. 10, p.277-281, 1972.

VALANCOGNE, C. Calcul du debit de sève methods du bilan de chaleur. Montpellier: INRA, s.d. $1 \mathrm{v}$.

VALANCOGNE, C.; NASR, Z. Measuring sap flow in the stem of small trees by heat balance method. HortScience, v.24, n.2, p.383-385, 1989.

VALANCOGNE, C.; NASR, Z. A heat balance method for measuring sap flow in small trees. In: BORGETTI, M.; GRACE, J.; RASCHI, A. et al. Water transport in plants under climatic stress. Cambridge: Univ. Cambridge Press, 1993. p.167-227.

VAN BAVEL, M.G.; VAN BAVEL, C.H.M. Dynagage installation and operation manual. Houston: Dynamax Inc., 1990. 80p. 
VIEWEG, G.H.; ZIEGLER, H. Thermoelektrische registrienung der geschwindigkeit des transpirationsstrones. Berichte Deutsche Botanische Gesellschaft, v.73, p.221-226, 1960.

WARING, R.H.; ROBERTS, J.M. Estimating water flux through stems of scots pine with tritiated water and phosphorus-32. Journal of Experimental Botany, v.30, n.116, p.459-471, 1979.

WEIBEL, F.P.; BOERSMA, K. An improved stem heat balance method using analog heat control. Agricultural and Forest Meteorology, v.75, p.191-208, 1995.

WEIBEL, F.P.; VOS, J.A. de. Transpiration measurements in apple trees an improved stem heat balance method. Plant and Soil, v.166, p.203-217, 1994.

ZHANG, J.; KIRKHAM, M.B. Sap flow in a dicotyledon (sunflower) and a monocotyledon (sorghum) by the heat-balance method. Agronomy Journal, v.87, p.1106-1114, 1995. 